\title{
MIĘDY AUTONOMIĄ A PAŃSTWOWOŚCIĄ. PRÓBY INSTYTUCJONALIZACJI STRUKTUR PRZEDSTAWICIELSKICH I WYKONAWCZYCH W UKRAINIE PO I WOJNIE ŚWIATOWEJ
}

\author{
BETWEEN AUTONOMY AND STATEHOOD. ATTEMPTS AT INSTITUTIONALIZING \\ REPRESENTATIVE AND EXECUTIVE STRUCTURES IN UKRAINE \\ AFTER THE FIRST WORLD WAR
}

One of the elements of constructing the Ukrainian statehood after the First World War was the establishment of representative and executive structures. First institutions - organs of authority - were founded in Trans-Dniester in the years 1917-1918. During the Ukrainian Revolution of 1917-1921, the Central Council of Ukraine was founded - during the All-Ukrainian National Congress it received the rank of the official representation of the state to be formed. The Council's weakness was the lack of influence within industrial and financial circles, as well as inability to create an effective administrative apparatus in Kyiv and throughout the country. The power was in fact exercised by the Provincial Government and its local structures. Nonetheless its greatest achievement was working out the foundations of coexistence with other nations inhabiting the territory of Ukraine. It is not widely known that in the Ukrainian land the so-called Jewish National Council, cooperating with the Central Council of Ukraine was established and vested with the initiative to regulate the matter of Jews' autonomy. The Central Council's alternative were central and local organs of representative authority created in the lands of Western Ukraine in the years 1918-1919. By the force of a resolution by the Ukrainian Parliamentary Representation (Lviv, 19 October 1918), the National Council of Ukraine (National Council) was established, which comprised Deputies to the Austro-Hungarian Parliament, the House of Lords, Sejm of Galicia and Sejm of Bukovina, as well as representatives of Ukrainian political parties - three of each party. The National Council was granted the status of a constituent assembly and a representative, lawmaking and administrative authorization to realize the right of self-determination of Ukrainians inhabiting the monarchy. By the force of the Council's decision in April 1919 acts were passed "On summoning the Sejm of the ZUNR" and "On electoral ordinance to the Sejm of the ZUNR", according to which a unicameral sejm (parliament) was to be the highest organ of the legislative power, established on the basis of the national criterion. Those organs ceased to exist along with the fall of the idea of establishing a Ukrainian state.

Słowa kluczowe: Ukraińska Centralna Rada, Żydowska Rada Narodowa, Ukraińska Rada Narodowa, parlamentaryzm ukraiński, system państwowy

Key words: Central Council of Ukraine, Jewish National Council, National Council of Ukraine, Ukrainian parliamentarism, state system

* Prof. Ivan Monolatii, Uniwersytet Przykarpacki im. Wasyla Stepanyka w Iwano-Frankiwsku, iwan.monolatij@gmail.com, https://orcid.org/0000-0002-8963-774X 


\section{STRUKTURY PRZEDSTAWICIELSKIE I WYKONAWCZE UKRAIŃSKIEJ WLADZY NA NADDNIEPRZU W LATACH 1917-1918}

W ujęciu chronologicznym pierwszą ukraińską władzą (ośrodkiem), która w okresie I wojny światowej, podczas ukraińskiej rewolucji w latach 1917-1921, zainicjowała reformowanie Ukrainy znajdującej się wówczas pod panowaniem Rosji, była Ukraińska Centralna Rada [dalej: UCR]. Jej przywódcy byli przekonani o konieczności szerokiego współdziałania w kontekście narodowościowym, wiedząc, że od sukcesu na tym polu będzie zależeć nie tylko intensywność ukraińskiego odrodzenia narodowego, ale także wynik podjętego wówczas wysiłku państwowotwórczego ${ }^{1}$. Konieczność takiej współpracy wyraźnie ujawniła się w pierwszej fazie rewolucji, kiedy demokratyczne siły ukraińskie oraz mniejszości narodowe podejmowały pierwsze działania zabezpieczające interesy swoich narodów. Z tego względu przewodniczący UCR, zwracając się de facto do mieszkającej na Ukrainie ludności nieukraińskiej wiosną 1917 r. stwierdził: „Występujemy o prawo państwowe dla ukraińskiej ziemi nie po to, by panować nad mniejszościami narodowymi Ukrainy [...]. Pełnia życia narodowego, o którą występujemy dla narodu ukraińskiego, nie powinna wchłonąć innych narodowości i ograniczać ich dążenia do swobodnego rozwoju własnego żywiołu kulturalnego i narodowego"'. M. Hruszewski, odpowiadając 30 marca 1917 r. w imieniu Centralnej Rady na list gratulacyjny Polskiego Komitetu Wykonawczego, podkreślił, że ,[...] Ukraińska Centralna Rada uznaje wszelkie prawa obywatelskie i polityczne wszystkich mniejszości narodowych, które zamieszkują na naszej Ukrainie i które uznają naród ukraiński za gospodarza na ukraińskiej ziemi oraz chcą wraz z nim iść jak wolni z wolnymi, równi z równymi $[\ldots]^{\prime \prime 3}$. W piśmie tym została wyrażona nadzieja, że Polacy tak samo uznają prawa Ukraińców, zamieszkujących ziemie etnicznie polskie.

Realizacja praw mniejszości narodowych miała polegać, zdaniem przewodniczącego Centralnej Rady, przede wszystkim na posługiwaniu się przez nie swoim językiem narodowym $w$ kontaktach $z$ urzędami i organami samorządowymi w okręgach, gdzie ich liczebność osiągnie określony pułap, na stworzenie warunków umożliwiających naukę w języku ojczystym w klasach, w których uczy się określona liczba uczniów (innej narodowości niż ukraińska), na powoływaniu towarzystw kulturalnych i religijnych, przyznaniu im pomocy finansowej z budżetu przyszłej autonomicznej Ukrainy oraz prawa do jej wykorzystania w celu zaspokojenia ich potrzeb. W miarę rozwoju rewolucji lista ta się rozszerzała. Jednocześnie Centralna Rada na każdym posiedzeniu, na którym były rozpatrywane ważne kwestie, zawsze podkreślała konieczność osiągnięcia porozumienia z mniejszościami narodowymi oraz zagwarantowania

${ }^{1}$ Vide I. Monołatij, M. Walak, Ukraińska idea państwowa - próby urzeczywistnienia, [w:] Wprowadzenie do studiów wschodnioeuropejskich, t. II, Ukraina i Białoruś: przeszłość i wspótczesność ziem między Rzeczypospolita a Rosja, red. W. Paruch, Lublin 2013, s. 148.

${ }^{2}$ M. Hruszewśkyj, Wilna Ukrajina, New York 1918, s. 17-18.

${ }^{3}$ Centralnyj derżawnyj archiw wyszczych orhaniw włady ta uprawlinnia Ukrajiny (m. Kyjiw), ф. 1115, оп. 1, спр. 2, арк. 11-12. 
im praw ${ }^{4}$. Takie podejście do sytuacji innych wspólnot narodowych, uwzględniające ich interesy, można uznać za wyjątkowe. Mychajło Hruszewski występował przeciwko wszelkim przejawom ,[...] ukraińskiego szowinizmu, poczucia wyjątkowości, nietolerancji wobec innych narodowości”. Nigdy nie były one „sympatyczne i pożądane”, lecz w ówczesnych warunkach, ,kiedy tak potrzebny jest takt i rozwaga, porozumienie i solidarność dla osiągnięcia wielkiego celu", nastroje ksenofobiczne były w ogóle niedopuszczalne. Stąd pojawił się słuszny postulat, aby uznać je za „narodową zbrodnię”, aby bezkompromisowo je zwalczaćs.

Kwestia narodowościowa zajmowała istotne miejsce w życiu społecznym i ukraińskim, i ogólnorosyjskim. Żadna partia polityczna nie mogła jej pominąć w swoim programie. Jakkolwiek większość partii konstytuowała się jako narodowe, a za swój cel uznawały obronę interesów swojej nacji, niemniej każda spośród nich proponowała własną koncepcję rozwiązania kwestii narodowościowej w sposób najbardziej odpowiadający interesom reprezentowanej przez siebie klasy bądź warstwy społecznej. Odpowiednie zapisy znalazły się w dokumentach programowych ukraińskich partii politycznych o orientacji prodemokratycznej. Demonstrując jedność w podstawowym postulacie programowym - przyznaniu Ukrainie autonomii narodowo-terytorialnej ${ }^{6}$ — jednocześnie mówiono w nich o konieczności ochrony interesów ludności nieukraińskiej. Wymóg ten został sformułowany w dokumentach programowych wielu ukraińskich partii i organizacji społecznych. Kwestia równoprawności mniejszości narodowych była również często podejmowana na mityngach i demonstracjach. W rezolucji pierwszej ukraińskiej pronarodowej demonstracji w Kijowie, która odbyła się 19 marca 1917 r., była mowa o potrzebie szerokiej autonomii dla ziem ukraińskich z uwzględnieniem praw mniejszości narodowych. Właśnie wówczas, zdaniem M. Hruszewskiego, rozpoczęło się „narodowe bratanie w miesiącu miodowym rewolucji”" ukraińskich i nieukraińskich organizacji rewolucyjnych.

Popularność idei równych praw dla mniejszości narodowych znajdowała również swój wyraz w publikacjach prasowych, np. w artykule „Wolą oraz prawem narodu ukraińskiego [...]”, opublikowanym 30 marca 1917 r. w „Gazecie Robotniczej” („Robitnycza Hazeta”), jeden z przywódców Ukraińskiej Socjal-Demokratycznej Partii Robotniczej [dalej: USDPR] M. Tkaczenko stwierdził, że po ustanowieniu autonomii mniejszości narodowe otrzymają wszelkie prawa polityczne, czyli będą brały udział w rządzeniu, otrzymają szkoły z narodowym językiem nauczania zarówno prywatne, jak i finansowane przez ukraiński organ państwowy, będą mogły posługiwać się językiem ojczystym we wszystkich urzędach, rozwijać swoją kulturę. W następnym numerze tej samej gazety został opublikowany artykuł członka Centralnej Rady D. Antonowycza, w której również była mowa o konieczności zagwarantowania praw mniejszościom

${ }^{4}$ M. Hruszewśkyj, Wilna Ukrajina..., s. 20.

5 Ibidem, s. 21.

${ }^{6}$ M. Panczuk, Nacionalni menszyny Ukrajiny u XX stolitti: polityko-prawowyj aspekt, Kyjiw 2000, s. 57.

7 M. Hruszewśkyj, Chto taki ukrajinci i czoho wony choczut', Kyjiw 1991, s. 29. 
narodowym ${ }^{8}$. Zarazem od mniejszości narodowych oczekiwano podobnej postawy. „Chcemy, ma się rozumieć, wierzyć - napisał M. Hruszewski — że również przedstawiciele mniejszości narodowych na Ukrainie odpowiednio zrozumieją swoją sytuację: ze swej strony wyjdą naprzeciw ukraińskim aspiracjom politycznym [...]"'. Podkreślił przy tym, że prawa mniejszości, w tym proporcjonalna reprezentacja $w$ organach władzy autonomii, zostaną im zagwarantowane niezależnie od tego, czy żywią one sympatię dla kwestii ukraińskiej, czy też nie.

Mniejszością, która w przypadku wprowadzenia w Rosji ustroju federacyjnego mogłaby stracić, była rosyjska. Utraciłaby ona dawne przywileje - dominującą pozycję w imperium. Ukraińscy przywódcy nie ukrywali tego i uznawali takie posunięcie za usprawiedliwione oraz konieczne nie tylko dla uciskanych w przeszłości nacji i wspólnot, ale również dla samych Rosjan. Jednak nie oznaczałoby to ograniczenia interesów żadnego z narodów zamieszkujących federację. „Pierwsza zasada ustroju federacyjnego jest taka, że obywatel jednej z ziem federacji korzysta z praw obywatelskich na obszarze całej federacji: oznacza to, że człowiek, który urodził się w Moskiewszczyźnie, będzie korzystał z pełni praw obywatelskich na przykład na Ukrainie, może tam skorzystać ze swojego prawa wyborczego, piastować urzędy, prowadzić biznes [...]"10. W taki sposób przywódca Centralnej Rady M. Hruszewski nie tylko postrzegał przyszłość mniejszości narodowych, ale również tworzył ją wraz z Radą. To właśnie Ukraińska Centralna Rada jako pierwsza w świecie podjęła realną próbę zagwarantowania praw ludności należącej do innych wspólnot narodowych. Rozwój mniejszości narodowych na Ukrainie odbywał się na podstawie przyjętej przez Radę ustawy o autonomii narodowej i osobistej, a wspierały go powołane przez nią sekretariaty ministerstwa spraw narodowościowych.

Centralna Rada miała świadomość tego, że chcąc zaktywizować walkę o autonomię Ukrainy w ramach zreformowanej Federacyjnej Republiki Rosyjskiej i gwarantując przy tym prawa ludności nieukraińskiej, powinna podnieść swój status. Przez wzgląd na to, finalizując tworzenie struktur Centralnej Rady jako „[...] rzeczywistego przedstawicielstwa całego zorganizowanego narodu ukraińskiego" ${ }^{11}$ oraz dążąc do ostatecznego wykrystalizowania się swego programu politycznego zwołała Ogólnoukraiński Kongres Narodowy.

Przedmiotem obrad tego Kongresu, które odbyło się w Kijowie w dniach 6-8 kwietnia 1917 r., było przede wszystkim poszukiwanie dróg rozwiązania kwestii narodowościowej oraz wybór nowego składu Centralnej Rady. Pierwsza z powyższych kwestii była przedstawiona w kilku referatach, natomiast bezpośrednio problemów mniejszości narodowych zamieszkujących na Ukrainie dotyczyły wystąpienia członka Centralnej Rady F. Matuszewskiego: „Autonomia szeroka i ograniczona, narodowo-terytorialna

${ }^{8}$ Ukrajinśkyj nacionalno-wyzwolnyj ruch. Berezeń, bystopad 1917 r. Dokumenty i materiały, oprac. W. Werstiuk, Kyjiw 2003, s. 101, 106.

9 M. Hruszewśkyj, Wilna Ukrajina..., s. 19-20.

${ }^{10}$ M. Hruszewśkyj, Chto taki ukrajinci i czoho wony choczut'..., s. 49-50.

11 Ibidem, s. 7. 
i narodowa. Wymóg szerokiej autonomii narodowo-terytorialnej dla Ukrainy. Prawa mniejszości narodowych oraz ich zagwarantowanie" oraz działacza społeczno-politycznego P. Poniatenki: „Ochrona interesów mniejszości narodowych”. F. Matuszewski po przeanalizowaniu światowych praktyk doszedł do wniosku, że każda mądra i sprawiedliwa władza powinna słuchać głosu mniejszości narodowych, zważać na ich interesy, poszukiwać dróg zagwarantowania mniejszościom wszelkich praw obywatelskich w życiu politycznym, społecznym, narodowym i religijnym. Jednocześnie traktował on mniejszości narodowe jako podmiot stosunków politycznych. Aby bronić swoich praw, miały one brać udział w wyborach ,[...] do wszystkich instytucji państwowych i regionalnych, do parlamentu, do lokalnych rad deputowanych na podstawie powszechnego,

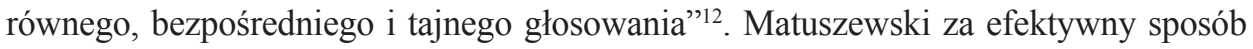
zapewnienia mniejszościom przedstawicielstwa uważał system proporcjonalny, w ramach którego reprezentanci mniejszości narodowych, dostawszy się do parlamentu czy też innego wybieralnego organu, $\mathrm{z}$ jednej strony otrzymywali prawo udziału w stanowieniu prawa, jak również reprezentowania interesów swoich wyborców, z drugiej zaś — kontroli jego przestrzegania oraz działań władzy wykonawczej.

Uzasadniając potrzebę przyznania Ukrainie autonomii narodowo-terytorialnej, która ,[...] uczyni naród ukraiński i pod względem prawno-państwowym, i realnie gospodarzem na swojej ziemi”, mówca podkreślił, że „,[...] autonomia ta obejmie wszystkie aspekty życia narodowości zamieszkujących ukraińską ziemię i tylko ona zapewni swobodny rozwój ich życia narodowego". Rozwój ten umożliwiałyby: oparta na demokratycznych zasadach ordynacja wyborcza; równość wszystkich obywateli wobec prawa; samorząd lokalny, uwzględniający potrzeby ludności o innej przynależności narodowej; zapewnienie wspólnotom narodowym proporcjonalnej reprezentacji w organach państwowych oraz ich praw do języka ojczystego ${ }^{13}$. Podsumowując, Matuszewski stwierdził, że autonomiczna Ukraina zagwarantuje mniejszościom narodowym pełnię praw.

Podobny w swej wymowie był również referat P. Poniatenki, który pokrótce omówiwszy strukturę narodowościową Ukrainy, więcej uwagi poświęcił analizie działalności trzech nurtów przeciwnych szerokiej autonomii narodowo-terytorialnej: neutralistów, zwolenników autonomii opartej na prawach historycznych, a nie na faktycznym prawie narodowej większości, oraz zwolenników autonomii eksterytorialnej. Mówca wymienił również podstawowe prawa, które zostałyby przyznane mniejszościom narodowym w przyszłej ukraińskiej autonomii narodowo-terytorialnej, w tym prawo do regularnego przeprowadzania zjazdów, które obierałyby stałe rady reprezentujące daną mniejszość w Radzie Krajowej; podział obwodów zamieszkanych przez mniejszości narodowe na okręgi sądowe i administracyjne, które zapewniałyby realizację ich praw w sądach i administracji; tworzenie szkół z ojczystym językiem nauczania, szkół mieszanych i klas równoległych — w zależności od liczby przedstawicieli mniejszości

\footnotetext{
${ }_{12}$ Ukrajinśkyj nacionalno-wyzwolnyj ruch. Berezeń, lystopad 1917 r..., s. 149.

${ }^{13}$ Ibidem, s. 153.
} 
narodowych w danej miejscowości; zapewnienie wolności wyznania i swobodnego rozwoju kultury poprzez ich finansowe wspieranie $\mathrm{z}$ krajowych środków ${ }^{14}$.

$\mathrm{Na}$ Ogólnoukraińskim Kongresie Narodowym przyjęto wiele rezolucji, w tym dotyczące kierunków rozwoju politycznego ruchu narodowego. Po pierwsze, delegaci kongresu uznali, że ,[...] jedynie rozległa szeroka autonomia narodowo-terytorialna Ukrainy zapewni realizację potrzeb naszego narodu oraz wszystkich innych narodowości zamieszkujących na ukraińskiej ziemi”. Przy czym z jednej strony zgadzali się w tym, że ,[...] prawo sankcji nowego ładu politycznego w Rosji, w tym także autonomii Ukrainy", należy do Rosyjskiego Zgromadzenia Ustawodawczego, z drugiej zaś podkreślali, że do czasu jego zwołania ,[...] zwolennicy nowego ładu na Ukrainie nie mogą być biernymi, lecz w porozumieniu z mniejszymi narodami na Ukrainie powinni bezzwłocznie tworzyć zręby jej autonomicznego życia"15. W tym celu Kongres polecił Centralnej Radzie powołać komitet dla opracowania projektu statutu autonomicznej Ukrainy, zaś w skład komitetu weszliby jego delegaci oraz przedstawiciele mniejszości narodowych. Po drugie, już w pierwszym dniu forum za jeden z filarów ukraińskiej autonomii została jednogłośnie uznana ,[...] pełna ochrona praw mniejszości narodowych zamieszkujących na Ukrainie". O wadze powyższej konstatacji świadczyło uzupełnienie, w którym uznano za konieczne ,[...] aby w krajach Federacyjnej Republiki Rosyjskiej, w których naród ukraiński stanowi mniejszość, narodowi ukraińskiemu zostały zagwarantowane prawa przysługujące mniejszościom na takich samych warunkach, na jakich na Ukrainie gwarantuje się prawa nieukraińskim mniejszościom"16. Po trzecie, za jedyną właściwą formę ustroju państwowego byłego imperium delegaci tego forum uznali „federacyjną i demokratyczną Republikę Rosyjską"17.

Zadeklarowanie przez ukraińskich demokratów w początkowej fazie ukraińskiej rewolucji dążenia do sprawiedliwego rozwiązania w Ukrainie kwestii narodowościowej było ważnym posunięciem, ponieważ w kraju krążyły pogłoski, że ludność nieukraińska nie ma przed sobą perspektyw na przyszłość. Z tego względu M. Hruszewski był zmuszony publicznie je dementować. W artykule „Czy Ukraina tylko dla Ukraińców?”, opublikowanym 15 kwietnia 1917 r., napisał: „Akurat uważamy, Ukraina nie tylko dla Ukraińców, a dla wszystkich, którzy mieszkają na Ukrainie, a mieszkając, ją kochają, a kochając, chcą pracować dla dobra kraju i jego ludności [...]. Każdy, kto wyznaje takie poglądy, jest naszym drogim współobywatelem, niezależnie od tego, kim by nie był Wielkorusem, Żydem, Polakiem, Czechem"18.

Drugim ważnym tematem obrad Ogólnoukraińskiego Kongresu Narodowego, dotyczącym mniejszości narodowych kraju, była reorganizacja Centralnej Rady. Jej przekształcenie z powołanego na zasadach koalicyjnych organu inicjatywnego pewnego

${ }^{14}$ M. Panczuk, Nacionalni menszyny Ukrajiny u XX stolitti: polityko-prawowyj aspekt..., s. 60.

${ }^{15}$ Ukraińska Centralna Rada. Dokumenty i materiaty, t. I, 4 września-9 grudnia 1917 r., red. W. Smolij, Kyjiw 1996, s. 54, 58, 61.

16 Ibidem, s. 54, 55, 59.

17 Ibidem, s. 54.

${ }_{18}$ M. Hruszewśkyj, Chto taki ukrajinci i czoho wony choczut'..., s. 106. 
ruchu czy też obozu politycznego w instytucję o charakterze ogólnonarodowym, w swoisty ukraiński organ ustawodawczy ${ }^{19}$, znacznie podniosło jej rangę. Zakładano również, że w przyszłości Centralna Rada stanie się jedynym organem przedstawicielskim kraju, w związku z czym przyznano jej prawo dokooptowania do swego składu 15\% „fachowców oraz przedstawicieli innych narodowości”, ogółem miała liczyć około 100-150 osób ${ }^{20}$. W związku z powyższym wybrany na przewodniczącego Centralnej Rady M. Hruszewski przedstawił na kongresie swoją koncepcję podstawowych zadań ukraińskiego procesu państwowotwórczego. W pierwszej kolejności miało to być utworzenie w terenie, począwszy od wsi do guberni, komitetów narodowych, które wraz z mniejszościami narodowymi zainicjowałyby tworzenie komitetów terytorialnych. Naczelnym organem tej struktury miała stać się Rada Krajowa, która byłaby platformą reprezentacji różnych regionów, miast, grup i narodowości ${ }^{21}$.

Centralna Rada, opierając się jedynie na realnej sile i rozszerzając swoją bazę społeczną mogła przystąpić do negocjacji z Rządem Tymczasowym, licząc na sukces. Działalność Centralnej Rady poparł ogólnoukraiński zjazd wojskowy, chłopski, a następnie także robotniczy, które odbyły się w Kijowie w maju i czerwcu 1917 r., a ich przedstawiciele zostali włączeni do jej składu. Wiosną 1917 r. stanowiła ona organ przedstawicielski jedynie tych sił politycznych i społecznych, które organizacyjnie popierały jej założenia programowe, czyli wchodziły w jej skład. Jednak Centralna Rada nie miała wpływów w kręgach przemysłowych ani w finansowych, nie dysponowała aparatem administracyjnym w Kijowie ani na prowincji. Realnie władzę sprawował Rząd Tymczasowy oraz jego struktury lokalne. Na tę okoliczność zwrócili uwagę delegaci Ogólnoukraińskiego Zjazdu Wojskowego, którzy w rezolucji „O administracji na Ukrainie" stwierdzili, że we wszystkich centralnych i lokalnych organach władzy ustawodawczej i wykonawczej, powinny być proporcjonalnie reprezentowane ,wszystkie nacje zamieszkujące na Ukrainie". Rezolucja ta została przyjęta przez zjazd w odpowiedzi na zarzuty przeciwników Centralnej Rady, że zarówno ona sama, jak i jej komitet wykonawczy nie mogą się uważać za rząd Ukrainy, gdyż reprezentują jedynie interesy społeczności ukraińskiej22.

W Centralnej Radzie wzrosło przekonanie o konieczności zintensyfikowania współpracy z przedstawicielami mniejszości narodowych po tym, jak w połowie maja 1917 r. delegacji ukraińskiej nie udało się uzyskać od Rządu Tymczasowego w Petersburgu przyznania Ukrainie szerokiej autonomii w ramach sfederalizowanej Rosji. Stanowisko to było widoczne w uchwałach zarówno Centralnej Rady, jak i innych sił ukraińskiego społeczeństwa, zwłaszcza w uchwałach wojskowych, w których była mowa o potrzebie współdziałania z mniejszościami narodowymi ${ }^{23}$.

${ }^{19}$ I. Chmil, Wseukrajinśkyj z'jizd rad selanśkych, robitnyczych i sołdatśkych deputatiw 1917, [w:] Encyktopedija istoriji Ukrajiny, t. I (A-W), Kyjiw 2003, s. 658.

${ }^{20}$ Ukraińska Centralna Rada. Dokumenty i materiaty..., t. I, s. 60.

${ }^{21}$ Ibidem.

${ }^{22}$ M. Panczuk, Nacionalni menszyny Ukrajiny u XX stolitti: polityko-prawowyj aspekt..., s. 61-62.

${ }^{23}$ Ukrainska Centralna Rada. Dokumenty i materiaty..., t. I, s. 87, 92-93, 101. 
Interesów ludności nieukraińskiej Centralna Rada nie pominęła również w I Uniwersale (10 czerwca 1917 r.). Proklamując autonomię ziem ukraińskich, z jednej strony zobowiązała ludność ukraińską, która ,żyje wespół z innymi narodowościami, [...] by bezzwłocznie doszła zgody i porozumienia z demokratami tych narodowości”, z drugiej zaś - wyraziła nadzieję, że mniejszości narodowe ,jednomyślnie wraz z nami przystąpią do pracy przy tworzeniu ukraińskiej autonomii”. W dokumencie tym znalazł się również zapis, że po sfinalizowaniu prac organizacyjnych Centralna Rada zwoła ,przedstawicieli wszystkich narodów ziemi ukraińskiej”, aby wspólnie opracować „dla niej prawa"24. Objaśniając następnie zapisy Uniwersału, przewodniczący Centralnej Rady M. Hruszewski przedstawił dwie zasadnicze tezy. Po pierwsze, podkreślił, że mniejszości narodowe będą bezpośrednio uczestniczyły w budowaniu ustroju ukraińskiej autonomii, jeżeli nie będą się one uchylały od współpracy z Ukraińcami. Po drugie, zapewnił, że dopóki przedstawiciele ludności nieukraińskiej w Ukrainie nie wejdą w skład Centralnej Rady, dopóty ona „nie pretenduje na jakąkolwiek władzę nad ludnością nieukraińską, jedynie nad narodem ukraińskim, który ją ustanowił"25.

W dwa tygodnie po przyjęciu I Uniwersału, 23 czerwca 1917 r., kwestia mniejszości narodowych była omawiana w Centralnej Radzie. Impulsem do tego była debata na temat statusu Sekretariatu Generalnego na czele z W. Wynnyczenkiem, który został powołany 15 czerwca 1917 r. przez Małą Radę (Komitet Centralnej Rady) jako stały organ decyzyjny. Zastępca sekretarza generalnego ds. narodowościowych O. Szulhyn, występując w imieniu Komitetu Centralnego Ukraińskiej Partii Demokratyczno-Liberalnej stwierdził: „Nie możemy obecnie mówić o rządzie Ukrainy, ponieważ w chwili obecnej stanowimy jedynie przedstawicielstwo narodowe, nie zaś całego terytorium Ukrainy. Ogłaszając Sekretariat Generalny rządem Ukrainy, dopuścilibyśmy się przemocy nad mniejszościami narodowymi" ${ }^{26}$. Z tego względu Szulhyn podkreślił, że ,[...] powinniśmy zmierzać i zmierzamy do tworzenia autonomicznego życia w porozumieniu z innymi narodowościami Ukrainy”. Centralna Rada podzieliła ów pogląd, jakkolwiek zaaprobowała powołanie Sekretariatu Generalnego oraz zatwierdziła jego skład, ostateczne głosowanie w tej sprawie odłożyła do czasu ogłoszenia deklaracji Sekretariatu ${ }^{27}$. Centralna Rada włączyła także przedstawicieli innych nacji do praktycznych działań na rzecz rozbudowy ukraińskiej autonomii narodowej. Mianowicie, liczebność powołanej trzy dni wcześniej komisji, która miała zająć się opracowaniem statutu autonomicznej Ukrainy, została powiększona z ośmiu do 100 osób zgodnie z zasadą przedstawicielstwa narodowo-terytorialnego. Nacje, które stanowiły w Ukrainie nie mniej niż 1\% populacji, delegowały do pracy w komisji swoich przedstawicieli (po jednym za każdy procent), te zaś, których liczebność nie przekraczała 1\%, upoważniały jedną wskazaną przez siebie osobę, którą następnie akceptowała komisja. Ostatecznie komisja liczyła 71 członków, w tym 11 Rosjan,

24 Ibidem, s. 104-105.

25 M. Hruszewśkyj, Chto taki ukrajinci i czoho wony choczut'..., s. 23-24.

26 Ukraińska Centralna Rada. Dokumenty i materiały..., t. I, s. 117.

27 Ibidem, s. 117, 120. 
Żydów — ośmiu, po dwóch Niemców i Polaków, po jednym Białorusinie, Tatarze, Mołdawianinie, Czechu, Greku i Bułgarze. Ogółem przedstawiciele ludności nieukraińskiej otrzymali w niej 29 miejsc. Powyższe proporcje odpowiadały strukturze narodowościowej ówczesnego społeczeństwa oraz ukazywały dążenia Ukraińców do konstruktywnej i równoprawnej współpracy ze wspólnotą nieukraińską na rzecz sprawy ogólnoukraińskiej ${ }^{28}$.

Porozumienie między Centralną Radą a mniejszościami narodowymi poprzedziły długie negocjacje między przedstawicielami Centralnej Rady a nieukraińskimi rewolucyjnymi demokratami. Jeszcze w przededniu zwołania Ogólnoukraińskiego Kongresu Narodowego zaczęły krążyć pogłoski, że Centralna Rada zamierza ogłosić autonomię Ukrainy bez zgody Rządu Tymczasowego i delegatów na mające się odbyć Ogólnorosyjskie Zgromadzenie Ustawodawcze. Niektórzy nawet utrzymywali, że „Ukraińcy chcą odłączenia". W celu wyjaśnienia tej sytuacji liderzy Komitetu Zrzeszonych Organizacji Społecznych, rad deputowanych robotniczych i wojskowych, koalicyjnej rady studenckiej podczas wspólnego posiedzenia z Centralną Radą 4 kwietnia 1917 r. zażądali od Ukraińców wyjaśnień w sprawie „tendencji separatystycznych”. M. Hruszewski, dementując pogłoski o bliskim ogłoszeniu przez mający się odbyć Ogólnoukraiński Kongres Narodowy odłączenia się Ukrainy od Rosji oraz protestując przeciwko groźbom, kierowanym pod adresem Ukraińców przez środowiska nieukraińskiej ,rewolucyjnej demokracji”, zadał obecnym na nim pytanie retoryczne: „Z kim myśmy się tu spotkali? Z przyjaciółmi czy z wrogami?"29. Równocześnie przewodniczący Centralnej Rady nie ukrywał, że Ukraińcy nie będą w milczeniu przyglądać się ignorowaniu ich interesów. „Flaga niepodległej Ukrainy czeka i zostanie rozwinięta wówczas, gdy flagę szerokiej ukraińskiej autonomii w federacyjnej i demokratycznej republice rosyjskiej ogólnorosyjscy centraliści będą chcieli wyrwać z naszych rąk" - napisał M. Hruszewski w artykule opublikowanym w gazecie „Nowa Rada” ${ }^{\prime 30}$.

W celu osłabienia napięcia i przyspieszenia szukania porozumienia, z inicjatywy nieukraińskich organizacji rewolucyjnych doszło do wspólnego „posiedzenia-wycieczki" na Dnieprze. Wynik tego spotkania był taki, że przedstawiciele mniejszości nie zanegowali konieczności powołania w Ukrainie specjalnego rewolucyjnego demokratycznego organu terytorialnego - Rady Krajowej, która reprezentowałaby interesy sił rewolucyjnych o orientacji prodemokratycznej w Ukrainie. Nieuzgodnione pozostawały szczegóły: w jaki sposób, o jakich uprawnieniach i w jakim składzie miałby taki organ powstać.

$\mathrm{Na}$ jednym ze wspólnych posiedzeń rewolucyjnych organizacji Kijowa oraz przedstawicieli Centralnej Rady w osobach M. Hruszewskiego i W. Wynnyczenki również była omawiana kwestia ewentualnego zwołania zjazdu krajowego i powołania organu krajowego, który reprezentowałby na Ukrainie Rząd Tymczasowy. Jego

${ }_{28}$ Ibidem, s. 107, 120, 125.

${ }^{29}$ P. Chrystiuk, Zamitky i materiały do istoriji ukrajinśkoji rewoluciji 1917-1920 r., t. I, Ńju-Jork 1969, s. 31.

${ }^{30}$ Centralnyj derżawnyj archiw hromadśkych objednań Ukrajiny (m. Kyjiw), ф. 5, оп. 1, спр. 265, с. 85. 
uczestnicy zdołali osiągnąć porozumienie i postanowili wypracować konkretne warunki do uchwalenia zawartych ustaleń ${ }^{31}$.

Kwestia porozumienia z mniejszościami narodowymi była przedmiotem debat nie tylko w Kijowie i Centralnej Radzie. Hasło wspólnego „tworzenia autonomicznego ładu" spotkało się z odzewem na całej Ukrainie. Przy tym zdarzało się, że działania na rzecz konsolidowania się znajdowały tam aplauz znacznie szybciej niż w Kijowie, np. w Połtawie miejscowa rada deputowanych robotniczych i wojskowych poparła I Uniwersał Centralnej Rady natychmiast po jego proklamowaniu. Kwestia porozumienia z demokratycznymi siłami mniejszości narodowych została również omówiona na I sesji Ogólnoukraińskiej Rady Deputowanych Chłopskich (22-24 czerwca 1917 r. $)^{32}$. Nieco wolniej proces wypracowywania porozumienia $\mathrm{z}$ innymi narodowościami przebiegał w wielkich miastach, gdzie duże wpływy miała inteligencja wychowana w duchu rosyjskiego centralizmu.

Dnia 24 czerwca 1917 r. Centralna Rada za „wielce pożądaną” uznała współpracę ze swoimi organami wykonawczymi nieukraińskich organizacji prodemokratycznych, zastrzegając przy tym, że współpraca taka jest możliwa pod warunkiem uznania przez nich Centralnej Rady za „najwyższy prawomocny organ narodu ukraińskiego" ${ }^{\prime 3}$. Postawienie kwestii w ten sposób wywołało opór ze strony przedstawicieli mniejszości narodowych. Inaczej niż Ukraińcy, którzy optowali za zreorganizowaniem Centralnej Rady w taki sposób, aby została ona proporcjonalnie uzupełniona o przedstawicieli ludności nieukraińskiej i postulowali utworzenie nowego organu terytorialnego. Przedstawiciele mniejszości narodowych uznali ukraińskie postulaty za uzasadnione i 26 czerwca 1917 r. podczas wspólnej konferencji wyrazili zgodę na „połączenie nieukraińskich organów rewolucyjnych z Ukraińską Centralną Radą" ${ }^{34}$. Zdaniem M. Hruszewskiego, to ustępstwo względem Ukraińców ze strony kijowskich kół ogólnorewolucyjnych w dużej mierze wynikało z tego, że w terenie pojawiły się problemy z zaopatrzeniem w artykuły żywnościowe i zamieszki na tym tle. Kwestia ta była omawiana 24 czerwca 1917 r. na sesji Centralnej Rady — w wystąpieniach stwierdzano, że ponieważ „Z północy nadciąga anarchia”, powołanie krajowego organu władzy stanowi konieczność. Opracowaniem projektu powołania takiego organu miała zająć się nowo utworzona komisja, w skład której weszli przedstawiciele partii i organizacji, w tym także mniejszości narodowych ${ }^{35}$. Kwestia reprezentacji mniejszości narodowych w Centralnej Radzie została ostatecznie rozstrzygnięta podczas rozmów z delegacją Rządu Tymczasowego, która przybyła do Kijowa 29 czerwca 1917 r., ponieważ oficjalne kręgi rosyjskie w Petersburgu były zaniepokojone stanem spraw na Ukrainie. Rezultaty ukraińsko-rosyjskich uzgodnień, w tym w kwestii narodowościowej, zostały ujęte w odrębnej deklaracji Rządu

\footnotetext{
31 P. Chrystiuk, Zamitky i materiały do istoriji ukrajinśkoji rewoluciji 1917-1920 r. t. I, ..., s. 85.

32 Ibidem, s. 89.

33 Ukraińska Centralna Rada. Dokumenty i materiały..., t. I, s. 124.

${ }^{34}$ P. Chrystiuk, Zamitky i materiały do istoriji ukrajinśkoji rewoluciji 1917-1920 r. t. I, ..., s. 88.

35 Ukraińska Centralna Rada. Dokumenty i materiały..., t. I, s. 122.
} 
Tymczasowego z 3 lipca oraz w II Uniwersale, w którym Centralna Rada wyraziła gotowość uzupełnienia swojego składu ,na sprawiedliwych podstawach o przedstawicieli innych narodowości”36. Ich reprezentacja miała stanowić jedną trzecią stanu osobowego ukraińskich instytucji. Zasadnicza zgoda przedstawicieli ludności nieukraińskiej na autonomię narodowo-terytorialną Ukrainy oraz akces do Centralnej Rady nastąpiła 26-28 czerwca 1917 r., chociaż wciąż nierozwiązany pozostawał problem proporcji liczbowych: Ukraińcy proponowali mniejszościom narodowym $25 \%$ miejsc w Centralnej Radzie, a one żądały ich połowy ${ }^{37}$.

Komisja ds. składu Centralnej Rady została powołana jeszcze 20 czerwca 1917 r. Weszło do niej po dwóch przedstawicieli eserowców, esdeków, radykalnych demokratów i bezpartyjnych. Podstawowym zadaniem tej Komisji był przegląd składu Centralnej Rady i opracowanie projektu uzupełnienia jej o ,przedstawicieli ukraińskiej nacji i mniejszości narodowych”. 28 czerwca 1917 r. Rada zatwierdziła „Postanowienia komisji w sprawie projektu uzupełnienia składu narodowościowego Ukraińskiej Centralnej Rady o przedstawicieli narodów, zamieszkujących na Ukrainie w mniejszości”. W dokumencie tym podkreślono, że o ile w Centralnej Radzie jest reprezentowane niemal całe spektrum rewolucyjnej demokracji ukraińskiej, w niektórych miastach już jest osiągane porozumienie z rewolucyjną demokracją nieukraińską i sytuacja polityczna sprzyja temu, by Centralna Rada stała się w Ukrainie centralną instytucją polityczną, o tyle powinna się zreorganizować i przekształcić w Tymczasowy Parlament Krajowy ${ }^{38}$.

Za najbardziej optymalny sposób uzupełnienia składu narodowościowego Centralnej Rady została uznana reprezentacja proporcjonalna. Zgodnie z tą koncepcją mniejszości narodowe miałyby otrzymać liczbę mandatów odpowiadającą liczebności populacji danej mniejszości na Ukrainie. Na zasady podziału mandatów wpływały sympatie polityczne Centralnej Rady: prawo do przedstawicielstwa przyznano w pierwszym rzędzie ,zorganizowanej demokracji rewolucyjnej”, a zatem radom deputowanych robotniczych i wojskowych oraz partiom socjalistycznym. Narodowości niereprezentowane w spektrum partii socjalistycznych mogły być reprezentowane przez organizacje ogólnonarodowe.

Po raz pierwszy przedstawiciele mniejszości narodowych oficjalnie podjęli współpracę ze zorganizowanym ruchem ukraińskim 11 lipca 1917 r., biorąc udział w otwartym posiedzeniu Małej Rady. Z chwilą ich przystąpienia do Centralnej Rady, stała się ona organem nie tylko przedstawicielstwa narodowego, lecz również terytorialnego. M. Hruszewski powitał nowych kolegów ,nie jako gości, a jako towarzyszy-współpracowników" i wyraził nadzieję, że to wszystko, co dzieliło Ukraińców i inne narody na Ukrainie zniknie i że w przyszłości będzie nie kilka rewolucyjnych demokracji, a jedna rewolucyjna demokracja Ukrainy. Właśnie wspólna praca Ukraińców i mniejszości narodowych miała wprowadzić Ukrainę „na drogę rozkwitu i pełnej zgody”39.

36 Ibidem, s. 163-164.
${ }_{37}$ Ibidem, s. 140, 540.
${ }_{38}$ Ibidem, s. 138.
${ }^{39}$ Ibidem, s. 175, 542. 
5 sierpnia 1917 r. rozpoczęła się VI sesja Centralnej Rady, w której obradach po raz pierwszy wraz z Ukraińcami wzięli również udział przedstawiciele mniejszości narodowych. Podobnie jak na posiedzeniu Małej Rady, niektórzy z nich, głównie Żydzi i Polacy, wygłosili przemówienia powitalne.

Najważniejszą spośród podjętych w dniach 15-16 lipca 1917 r. decyzji w sprawie reorganizacji Sekretariatu Generalnego było uzupełnienie jego składu o przedstawicieli trzech najliczniejszych mniejszości narodowych — Rosjan, Żydów i Polaków, których reprezentanci zostali powołani na zastępców sekretarza generalnego do spraw narodowościowych. Kandydatury na te stanowiska zatwierdzała Mała Rada. Przy nich miały zostać utworzone ciała doradcze, w skład których mieli wejść przedstawiciele partii narodowych ${ }^{40}$. Każdemu z zastępców sekretarza narodowego zostało przyznane prawo decydującego głosu przy rozpatrywaniu spraw dotyczących jego narodu. Wszystkie ustawy, przepisy i rozporządzenia administracyjne w języku ukraińskim, publikowane były również w języku rosyjskim, jidysz oraz polskim ${ }^{41}$.

Odpowiednio do wspomnianego już „Regulaminu Generalnego Sekretariatu do Spraw Narodowościowych" Generalny Sekretariat miał dysponować kancelarią, składającą się z dwu wydziałów: informacyjnego oraz spraw ogólnych. Ponadto każdy zastępca sekretarza dysponował własną kancelarią. Przewidziana została również instytucja specjalnej narady i rady przy Sekretariacie. Pierwsza miała zajmować się rozstrzyganiem kwestii spornych oraz spraw dotyczących ludności nieukraińskiej. Tworzyli ją sekretarz generalny oraz jego trzej zastępcy. Jednak gdyby problemu nie udało się rozwiązać na tym poziomie, rozpatrywał ją Sekretariat Generalny. Rada Narodowa przy sekretarzu do spraw narodowościowych omawiała najważniejsze działania Sekretariatu z udziałem przedstawicieli danej narodowości w Małej Radzie oraz partii i grup politycznych. Na niższych szczeblach (w terenie) zostały utworzone stanowiska lokalnych komisarzy do spraw narodowych, a także odpowiednio - komitety powiatowe i lokalne, które miały koordynować pracę i zajmować się sprawami społeczności lokalnych ${ }^{42}$.

Wszystkie rozporządzenia Sekretariatu Generalnego oraz jego struktur, dotyczące spraw wewnętrznych i praw mniejszości narodowych, wchodziły w życie dopiero po ich parafowaniu przez właściwego zastępcę sekretarza generalnego do spraw narodowych. Językiem komunikacji wewnętrznej podsekretariatów miał być język właściwej mniejszości narodowej ${ }^{43}$. Sposób, w jaki przywódcy ukraińskiej rewolucji podchodzili do sprawy innych narodowości, jednoznacznie świadczył o ich dążeniu do porozumienia się z innymi narodami mieszkającymi w kraju. Głównym zadaniem zastępców sekretarza generalnego do spraw narodowościowych była ochrona praw mniejszości narodowych na Ukrainie oraz ochrona swobodnego rozwoju ich życia narodowego. W szczególności,

40 Ibidem, s. 179, 181, 542.

41 Ibidem, s. 181, 182.

${ }^{42}$ O. Kudłaj, Stworennia ta dijalnist' narodnoho ministerstwa miżnarodnych spraw Ukrajinśkoji Narodnoji Respubliky (czerweń 1917 - kwiteń 1918 rr.), Kyjiw 2008, s. 16.

43 S. Goldelman, Żydiwśka nacionalna awtonomija w Ukrajini 1917-1920, Miunchen-Paryż-Jerusałym 1967, s. 57. 
odpowiednio do polecenia szefa Sekretariatu z 27 lipca 1917 r., mieli oni zapewniać ochronę przed ograniczaniem mniejszościom praw obywatelskich i politycznych, stwarzać odpowiednie warunki dla działalności organizacji narodowych. Zastępcy mieli także co tydzień składać szefowi urzędu sprawozdania ze swej pracy ${ }^{44}$.

Dowodem prawdziwości intencji Centralnej Rady odnośnie do przyznania mniejszościom narodowym możliwości samodzielnego decydowania o kształcie swojego funkcjonowania na terenie Ukrainy było podniesienie statusu wicesekretarzy do spraw rosyjskich, żydowskich i polskich. Na mocy uchwały Centralnej Rady z listopada $1917 \mathrm{r}$. otrzymali oni prawo decydującego głosu na posiedzeniach rządu, a także miano „komisarzy do spraw narodowości polskiej, żydowskiej i rosyjskiej na prawach sekretarzy generalnych". Sekretariat Generalny porozumiał się z mniejszościami narodowymi również co do liczby ich przedstawicieli w rządzie - weszło do niego sześciu reprezentantów mniejszości. Oprócz trzech komisarzy narodowych oraz pełniącego obowiązki sekretarza generalnego poczty i telegrafu, byli jeszcze dwaj członkowie rządu bez teki, z których jeden miał łączyć to stanowisko z obowiązkami narodowego kontrolera. Dnia 7 listopada 1917 r., z okazji ogłoszenia III Uniwersału, Mała Rada awansowała wszystkich trzech komisarzy generalnych z prawami sekretarzy generalnych, w tym do spraw narodowości rosyjskiej, żydowskiej oraz polskiej, na pełnoprawnych sekretarzy generalnych ${ }^{45}$.

Po tym jak 22 grudnia 1917 r. na bazie Sekretariatu Generalnego do Spraw Narodowościowych powołany został Sekretariat Generalny do Spraw Międzynarodowych, przedstawicielstwa narodowe ostatecznie przekształciły się w odrębne sekretariaty — do spraw rosyjskich, żydowskich oraz polskich ${ }^{46} .9$ stycznia 1918 r., odpowiednio do postanowień IV Uniwersału, został zreorganizowany ukraiński rząd. Sekretariat Generalny przekształcono w Radę Ministrów, sekretariaty, w tym narodowe, stały się ministerstwami. Ta druga zmiana miała szczególny wymiar dla Żydów, gdyż był to „pierwszy w historii przypadek utworzenia żydowskiego ministerstwa” — co później odnotował I. Czerykower ${ }^{47}$.

Działalność Sekretariatu/Ministerstwa do Spraw Żydowskich jako organu władzy państwowej sprowadzała się do realizacji dwóch podstawowych zadań: obrony interesów mniejszości żydowskiej, praw obywatelskich i politycznych jej członków oraz rozwoju żydowskiej autonomii narodowej na Ukrainie, tworzenia jej instytucji lokalnych i centralnych. Program działalności sekretariatu/ministerstwa został przedstawiony już w pierwszej deklaracji jego szefa z 1 października 1917 r., zaprezentowanej na posiedzeniu nowo powołanej Żydowskiej Rady Narodowej (ŻRN) ${ }^{48}$. W dokumencie

${ }^{44}$ O. Kudłaj, Stworennia ta dijalnist' narodnoho ministerstwa miżnarodnych spraw Ukrajinśkoji Narodnoji Respubliky (czerweń 1917 - kwiteń 1918 rr.), s. 16-17.

${ }^{45}$ Ukraińska Centralna Rada. Dokumenty i materiaty..., t. I, s. 398, 566.

${ }^{46}$ Ukraińska Centralna Rada. Dokumenty i materiaty, t. II, 10 grudnia 1917 r.-29 kwietnia1918 r., red. W. Smolij, Kyjiw 1997, s. 61.

${ }^{47}$ I. Czerykower, Antysemityzm i pogromy na Ukrainie 1917-1918 (K istorii ukrainsko-jewrejskich otnoszenij), Berlin 1923, s. 67.

48 S. Goldelman, Żydiwśka nacionalna awtonomija w Ukrajini 1917-1920.., s. 57, 112. 
tym, oprócz przywołania ogólnych norm demokratycznych w zakresie ochrony praw narodowych, zostały sformułowane jego najważniejsze zadania:

1. Wspólnie z Żydowską Radą Narodową opracować projekt Statutu Żydowskiej Autonomii Narodowej, który miało zatwierdzić przeprowadzone w demokratyczny sposób Żydowskie Zgromadzenie Narodowe. Miało ono również powołać narodowy organ, przed którym sekretariat/ministerstwo odpowiadałoby za swoją działalność.

2. Utworzyć żydowski samorząd, którego podstawę miały stanowić gromady, mogące połączyć ,przyszłość [...] narodowego samorządu z jego przeszłością”. W tym celu konieczne było stworzenie podstaw prawnych umożliwiających reformowanie społeczności żydowskich, tak by ich funkcjonowanie było zgodne z zasadami demokracji, samorządności oraz społecznym zapotrzebowaniem, a także powołanie demokratycznych rad społecznych, wybieranych przez całą żydowską społeczność.

3. Zdemokratyzować politykę podatkową w gromadach.

4. Zapewnić rozwój obowiązkowej edukacji szkolnej i pozaszkolnej, odpowiadającej światowym standardom.

5. Ustawowo uregulować prawa, ,języka żydowskiego w życiu społecznym i politycznym, na równi z prawami innych języków kraju".

6. Bronić godności i honoru narodu żydowskiego, ,aby nie dopuścić do powtórzenia się przestępczych działań antysemickiej polityki rządu carskiego" ${ }^{\text {"49 }}$.

Sekretariat/Ministerstwo do Spraw Żydowskich starając się reprezentować interesy ukraińskich Żydów w URL wszelkimi sposobami broniło jego praw. Przede wszystkim dotyczyło to walki z pogromami, które - niezależnie od tego, kto sprawował władzę - niemal przez cały czas trwania rewolucji były jej ,smutnymi towarzyszami”. Owo stałe niebezpieczeństwo należało do głównych problemów i trosk w pracy żydowskiego resortu ${ }^{50}$.

Duże znaczenie miała działalność powołanej pod koniec września 1917 r. Żydowskiej Rady Narodowej [dalej: ŻRN]. Byli w niej reprezentowani na zasadach parytetu włączeni do Centralnej Rady, przedstawiciele pięciu żydowskich partii politycznych: trzech socjalistycznych: Bundu, ОССРП i Poalej Sion („Robotnicy Syjonu") oraz JNP, a także syjonistów. Na początku Rada liczyła 25 członków (po pięciu z każdej partii), następnie partyjne przedstawicielstwo zostało podwojone i ostatecznie jej liczebność powiększyła się do 50 osób. Niemniej nie odpowiadało to syjonistom, którzy uważali, że w środowiskach żydowskich cieszą się większym poparciem niż partie socjalistyczne, dlatego domagali się dla ŻRN przedstawicielstwa proporcjonalnego (a nie parytetowego) ${ }^{51}$. Otrzymawszy odmowę, podali w wątpliwość moralne prawo ówczesnego żydowskiego szefa do reprezentowania w państwie nacji żydowskiej i podjęli decyzję o bojkocie działalności Rady, wychodząc z niej już w trakcie pierwszego posiedzenia 1 października 1917 r. Później syjoniści

\footnotetext{
49 Ibidem, s. 57-58.

50 Ibidem, s. 75.

51 Ibidem, s. 60-62, 66, 112.
} 
sporadycznie i jedynie w celach ściśle informacyjnych przysyłali swojego przedstawiciela ${ }^{52}$.

Początkowo ŻRN nie stanowiła reprezentacji politycznie aktywnej i cieszącej się autorytetem. Pełniła funkcje doradcze przy wicesekretarzu do spraw żydowskich, a jej rekomendacje i postanowienia formalnie nie były obligatoryjne. Dopóki nie powstały centralne organy żydowskiej autonomii, dopóty de facto reprezentował je sam szef, który jako „oficjalny przedstawiciel nacji żydowskiej w państwie” pełnił „funkcje organu wykonawczego równolegle $\mathrm{z}$ reprezentowaniem nacji" ${ }^{53}$. Jednak sytuacja ta się wkrótce zmieniła. Konieczność przeprowadzenia zmian ujawniła się, gdy powstały pierwsze demokratycznie wybrane lokalne organy autonomii. Właśnie wówczas zaczął się uwidaczniać pewien rozdźwięk między stanowiskiem żydowskiego ministra jako pełnoprawnego członka rządu, odpowiedzialnego przed parlamentem państwa, a jego pozycją względem autonomicznych żydowskich organów, gdzie mogła powstać większość o innym podejściu do istotnych kwestii politycznych, kulturalnych niż prezentowana przez większość parlamentarną, rząd oraz tegoż żydowskiego ministra. Taka właśnie sytuacja zdarzyła się podczas wyborów lokalnych do żydowskich rad społecznych (kagalnych), przeprowadzonych na mocy ustawy z 2 grudnia 1917 r. Rozwijając autonomię narodową i osobistą, przywódcy mniejszości żydowskiej mieli świadomość, że instrumentem jej wzmocnienia będzie demokratycznie wybrany parlament — Żydowskie Zgromadzenie Ustawodawcze. Jego podstawowym zadaniem było zapewnienie demokratycznych zasad funkcjonowania żydowskiej autonomii oraz uchwalenie ustaw, koniecznych jako baza prawna i finansowa działalności żydowskich gromad. Opracowanie projektu ustawy o zwołaniu Żydowskiego Zgromadzenia Ustawodawczego i jego przeprowadzenie na posiedzeniu Centralnej Rady zlecono Żydowskiej Radzie Narodowej. Jednocześnie działacze żydowscy zabezpieczyli się alternatywnym scenariuszem, czyli zwołaniem ,przedparlamentu” (Tymczasowego Zgromadzenia Narodowego), którego członkowie zostali wybrani przez miejscowe gromady. Planowane to było na wypadek, gdyby przeprowadzenie wyborów powszechnych okazało się niemożliwe ze względu na sytuację polityczną $a^{54}$. Punktem wyjścia dla wyborów miało stać się zwołanie Ukraińskiego Zgromadzenia Ustawodawczego, które zostało zaplanowane na 12 maja 1918 r. Żydowska Rada Narodowa zamierzała utworzyć „,wstępny” przedparlament i równocześnie w lipcu przeprowadzić wybory powszechne do Żydowskiego Zgromadzenia Ustawodawczego tak, aby zostało ono zwołane na początku sierpnia tego roku. Niemniej bieg wydarzeń pokazał, że Żydzi mieli słuszność. Niezależnie od tego, że wspomniany projekt ustawy o zwołaniu Żydowskiego Zgromadzenia Ustawodawczego został opracowany, a nawet wniesiony pod obrady Centralnej Rady, nie było mu dane stać się ustawąą.

${ }^{52}$ I.B. Szechtman, Jewrejskaja obszczestwiennost'na Ukrainie (1917-1919 r.), [w:] Kniga o russkom jewriejstwie. 1917-1967, New Jork 1968, s. 25.

53 S. Goldelman, Żyiwśka nacionalna awtonomija w Ukrajini 1917-1920..., s. 59, 112.

${ }^{54}$ Ibidem, s. 81-82.

${ }^{55}$ Ibidem, s. 82. 
Aktywną działalność rozwinął również Sekretariat do Spraw Polskich. Ważnym momentem uczestnictwa Polaków w strukturach władzy wykonawczej i samoorganizacji polskiej mniejszości w narodowym i kulturalnym odrodzeniu było zreformowanie Sekretariatu Generalnego do Spraw Narodowościowych. Tworzenie wicesekretariatu, który liczył 80 osób i składał się wyłącznie z Polaków wyłonionych przez polskie siły polityczne, trwało stosunkowo długo — realnie zaczął on funkcjonować dopiero w październiku 1917 r. Jego działalność sprzyjała konsolidacji Polaków, tworzeniu przez nich gromad, aktywizacji polskich partii na ukraińskiej scenie politycznej ${ }^{56}$. Do jego najaktywniejszych wydziałów należał oświatowy, który opiekował się szkołami podstawowymi i średnimi, szkolnictwem zawodowym i edukacją pozaszkolną, a także wspierał szkoły prywatne. Istotnym segmentem w działalności wydziału była praca dokumentacyjna, polegająca głównie na zbieraniu danych statystycznych na temat polskich uczniów pobierających naukę w szkołach na terenie Ukrainy, a następnie analizie tych danych. Pracownicy wydziału ogólnego troszczyli się o uchodźców z Polski, wspierali ich powrót do ojczyzny, pomagali bezrobotnym Polakom, organizowali działalność prawną i informacyjną, podejmowali działania na rzecz ochrony osób narodowości polskiej przed rekwizycjami i pogromami ${ }^{57}$. Wydział wydał pokaźną liczbę dokumentów poświadczających wartość kulturalną i artystyczną wielu majątków. Jednak nie zostało to poprzedzone analizą ich rzeczywistej wartości i dlatego umniejszało status zabytków oraz prowadziło do utraty zaufania do Centralnej Rady, która — zdaniem chłopów - wydając właścicielom ziemskim tego rodzaju dokumenty ochronne, broniła w ten sposób ich interesów. Najmniej efektywną była działalność wydziału gospodarczo-spółdzielczego polskiego przedstawicielstwa narodowego, który miał zbierać dane o potrzebach ekonomicznych ludności polskiej i organizacyjnie wspierać ją w tym zakresie. Realnie tego rodzaju działania uniemożliwiała złożona sytuacja społeczno-polityczna na Ukrainie, ogólny kryzys gospodarczy, wywołany wydarzeniami I wojny światowej oraz narastającą w kraju anarchią po przejęciu władzy w Rosji przez bolszewików ${ }^{58}$.

Pod koniec listopada 1917 r. wicesekretariat do spraw polskich wchodzący w skład Sekretariatu Generalnego został przekształcony w odrębny Sekretariat Generalny do Spraw Polskich, zaś w styczniu 1918 r. został on przemianowany na ministerstwo, które miało reprezentować interesy i ochraniać prawa polskiej mniejszości w URL, wspierać powstawanie gromad narodowych oraz działalność kulturalno-oświatową Polaków $^{59}$. Struktura Ministerstwa do Spraw Polskich [dalej: MSP] zasadniczo pozostała taka sama, chociaż zostały wprowadzone w niej pewne zmiany: 13 stycznia 1918 r. powołano Departament Samorządu Narodowego. Zadaniem nowej ministerialnej komórki było opracowanie narodowego katastru, przygotowanie list wyborczych i przeprowadzenie wyborów do zebrania założycielskiego Polskiego Związku

${ }^{56}$ H. Jabłoński, Polska autonomia narodowa na Ukrainie 1917-1918, Warszawa 1948, s. 55-56, 114.

${ }^{57}$ Centralnyj derżawnyj archiw wyszczych orhaniw włady ta uprawlinnia, f. 2201, оп. 1, спр. 7, арк. 7.

${ }^{58}$ H. Jabłoński, Polska autonomia narodowa na Ukrainie 1917-1918..., s. 58-59.

${ }^{59}$ Centralnyj derżawnyj archiw wyszczych orhaniw włady ta uprawlinnia... 
Narodowego, które były przewidziane w ustawie o autonomii narodowej i osobistej, powołanie lokalnych przedstawicielstw MSP, monitorowanie potrzeb ekonomicznych i narodowych ludności polskiej ${ }^{60}$. Zasadniczo MSP nie pracowało efektywnie z powodu rywalizacji z Polskim Komitetem Wykonawczym [dalej: PKW], który prowadził podobną działalność, niemniej cieszył się wsparciem większości ludności polskiej na ukraińskich ziemiach, np. na Wiecu Narodów, które odbyło się na terenie kijowskiego cyrku 29 listopada 1917 r., właśnie PKW występował w imieniu wszystkich Polaków. Ponadto PKW dysponował siecią przedstawicielstw w guberniach i powiatach (miał tam swoich komisarzy i działające przy nich rady), zbierał na swoją rzecz podatek od „świadomych" Polaków ${ }^{61}$.

Mniejszość polska posiadała na ukraińskich ziemiach dwie formy autonomii: 1) legitymizowane przez państwo, lecz mało wpływowe Ministerstwo do Spraw Polskich wchodzące w skład ukraińskiego rządu; 2) PKW, który dysponując własnymi strukturami w terenie, systemem podatkowym, a nawet siłami zbrojnymi (zorganizowanymi oddziałami polskiej milicji), był $\mathrm{w}$ istocie państwem w państwie. $\mathrm{Z}$ tych powodów podporządkowanie się polskiej mniejszości Radzie nie było rzeczą prostą: przeciętny Polak na Ukrainie, mając dostęp do „bardziej ojczystej” polskiej władzy, nie zawsze był gotów podporządkować się władzy ukraińskiej. Powyższa sytuacja podważała zasady ukraińskiej autonomii ${ }^{2}$. Opanowanie Kijowa przez bolszewików, którzy przed swą ucieczką z miasta spalili gmach, w którym miało swoją siedzibę MSP, a następnie przewrót hetmański — wszystko to znacząco ograniczyło realizację programu odrodzenia kulturalno-oświatowego mniejszości polskiej. W sierpniu 1918 r. MSP zostało oficjalnie rozwiązane, niemniej niektóre jego jednostki działały jeszcze przez pewien czas.

Ministerstwo do Spraw Rosyjskich, w odróżnieniu od narodowego przedstawicielstwa żydowskiego i polskiego, przez dłuższy czas nie przejawiało jakiejś szczególnej aktywności. Początkowo nawet utworzone dla Rosjan stanowisko zastępcy sekretarza generalnego spraw narodowościowych było nieobsadzone. Najpierw (15 lipca) tłumaczyli oni to tym, że jeszcze nie są w stanie zaproponować odpowiedniego kandydata, a następnie (21 sierpnia) - brakiem ludzi do pracy ${ }^{63}$. W tej inercji mniejszości rosyjskiej badacze upatrują protekcjonalny stosunek Rosjan do przywódców ukraińskiego ruchu narodowego oraz nieżyczliwy stosunek wielu liderów Centralnej Rady do Rosjan. Na zebraniach i sesjach Centralnej Rady często używano określenia „kacap”, nie mówiąc już o tym, że słowo „Moskal” niemal zupełnie wyparło słowo „Rosjanin”. Stanowiło to swoiste pokłosie długotrwałej rusyfikacji Ukrainy i pogardliwego stosunku imperialnej stolicy do „Małorusinów”. Poniekąd i w czasach Centralnej Rady niektórzy Rosjanie w Ukrainie bezceremonialnie naruszali porządek społeczny z powodów

${ }^{60}$ Ibidem, арк. 7 (зв.), 8.

${ }^{61}$ W. Skalśkyj, Polityczne żyttia polśkoji hromady pid czas Ukrajinśkoji rewoluciji (berezeń 1917-kwiteń 1918 rr.), [w:] „Ukrajinskyj Istorycznyj Zbirnyk” 2008, nr 11, s. 195.

62 Ibidem, s. 188-198.

${ }^{63}$ Ukraińska Centralna Rada. Dokumenty i materiały..., t. I, s. 175, 264, 345-346, 386-387. 
politycznych ${ }^{64}$. Szczyt aktywności Ministerstwa do Spraw Rosyjskich przypadł na wiosnę 1918 r., a zatem pod koniec działalności samej Centralnej Rady. Resort tworzyły dwa departamenty — spraw ogólnych i powszechnej oświaty, a także trzy wydziały: autonomii narodowej i osobistej, statystyczny oraz sztuki. 23 marca 1918 r. został utworzony wydział „pomocy dla Wielkorusów”, który miał się zająć zorganizowaniem ewakuacji rosyjskich uchodźców i wojskowych do ich ojczyzny. Wiosną 1918 r. przy ministerstwie zaczęła funkcjonować komórka zajmująca się sprawami zatrudnienia Biuro Pracy. W drugiej połowie 1918 r. rozpoczęło się tworzenie wydziału książkowo-bibliotecznego oraz archiwum. Sprawy administracyjne były wyjątkowo prowadzone w języku rosyjskim ${ }^{65}$.

Ukraińskie ciała państwowe w latach 1917-1918, wybierając między dwoma modelami narodu politycznego: naród-państwo (nation-state) a państwo-naród (state-nation), opowiedziały się za tym drugim. Została przez nie uznana więcej niż jedna „tożsamość kulturowa” i poprzez wsparcie instytucjonalne starano się kształtować model licznych nawzajem się uzupełniających pomniejszych tożsamości. Walcząc o sprawiedliwość społeczną oraz restytucję narodowej państwowości przedstawiciele władz ukraińskich za jeden z podstawowych elementów walki wyzwoleńczej uznali stworzenie warunków dla etnokulturowej niezawisłości oraz rozwoju politycznego mniejszości narodowych. Centralna Rada Ukraińska po raz pierwszy w światowej praktyce podjęła realną próbę zagwarantowania praw mieszkającej w Ukrainie ludności innej etnicznie. Podstawą rozwoju narodowego mniejszości w URL była ustawa o autonomii narodowej i personalnej, a także powołane sekretariaty/ministerstwa do spraw narodowych.

\section{CENTRALNE I LOKALNE ORGANY WLADZY PRZEDSTAWICIELSKIEJ NA ZIEMIACH ZACHODNIOUKRAIŃSKICH W LATACH 1918-1919}

Powstanie, tworzenie centralnych i lokalnych organów przedstawicielskich władzy w Zachodnioukraińskiej Republice Ludowej (ZURL, następnie Zachodni Obwód Ukraińskiej Republiki Ludowej - ZOURL) odbywało się w warunkach upadku monarchii austro-węgierskiej i „marszu niepodległości” narodów zamieszkujących to państwo. Okoliczności te każą uwzględniać fakt, że ukraińska scena polityczna w Galicji była przesiąknięta tradycjami austriackiego konstytucjonalizmu, była genetycznie związana ze starymi monarchicznymi strukturami przedstawicielskimi i de facto stanowiła ich emanację. Na mocy uchwały Ukraińskiej Reprezentacji Parlamentarnej z 18 października 1918 r. we Lwowie odbyło się zebranie mianowanych przez nią członków Ukraińskiej Rady Narodowej (Rada Narodowa), do której weszli posłowie do parlamentu austro-węgierskiego (25), Izby Panów (2), Sejmu Galicyjskiego (14) i Bukowińskiego (6) oraz przedstawiciele ukraińskich partii politycznych — po trzech od każdej

${ }^{64}$ O. Myronenko, Heneralne sekretarstwo (ministerstwo) z rosijśkych spraw URL, [w:] Mała encyklopedija etnoderżawoznawstwa, Kyjiw 1996, s. 272-273.

${ }^{65}$ Ibidem, s. 273. 
spośród nich ${ }^{66}$. Zgodnie z przyjętym Statutem, Rada Narodowa otrzymała status konstytuanty oraz pełnomocnictwa o charakterze reprezentacyjnym, prawodawczym i administracyjnym w celu urzeczywistnienia prawa Ukraińców mieszkających w monarchii do samookreślenia. Zaś 19 października 1919 r. odbyło się Ogólnonarodowe Ukraińskie Zgromadzenie Narodowe, w którym wzięło udział 2 tysiące „mężów zaufania” z terenu całej Galicji. Uczestnicy tego forum zatwierdzili Statut Rady Narodowej, zaaprobowali historyczną uchwałę o utworzeniu państwa ukraińskiego na ziemiach etnicznie ukraińskich wchodzących w skład monarchii oraz zobowiązali Radę do opracowania tekstu konstytucji, gwarantującej obywatelom powszechne, równe prawo wyborcze oraz autonomię kulturalną mniejszościom narodowym. Obrano również Prezydium Rady Narodowej, które miało ją reprezentować w okresie międzysesyjnym ${ }^{67}$.

Powołaną w dniach 18-19 października 1919 r. Radę Narodową można uznać za najwyższy przedstawicielski organ prawodawczy narodu ukraińskiego w Galicji Wschodniej, jakkolwiek występowała do rządu wiedeńskiego o uznanie (legitymizowanie) ukraińskiej państwowości, która nie była jeszcze faktem dokonanym. Po zrywie listopadowym Rada Narodowa realnie przejęła uprawnienia w zakresie sprawowania władzy oraz w odpowiedni sposób usytuowała się względem ludności kraju i świata zewnętrznego. Ważne znaczenie dla legitymizacji prawomocności Rady Narodowej miało oficjalne przekazanie władzy Radzie Narodowej w Galicji Wschodniej 1 listopada 1918 r. przez namiestnika W. Decykewicza. Wydała ona wówczas dwie odezwy, informując w nich, że ,z dniem dzisiejszym” przejmuje władzę w całym państwie ukraińskim, oraz stwierdzając, że w jej imieniu „organy władzy państwowej w trybie zgodnym z prawem mają przejąć władzę we wszystkich powiatach, miastach i wsiach". Do wsparcia tych działań wezwano ukraińskich żołnierzy oraz mniejszości narodowe. Rada Narodowa zobowiązała się do ogłoszenia składu i programu powołanego przez siebie rządu oraz do zwołania „na podstawie powszechnego, równego, bezpośredniego i tajnego prawa wyborczego" Zgromadzenia Ustawodawczego, które określi przyszły kształt Państwa Ukraińskiego ${ }^{68}$.

Ważnym momentem w stanowieniu zachodnioukraińskiego państwa oraz jego centralnych instytucji przedstawicielskich było uchwalenie 13 listopada 1918 r. „Tymczasowej ustawy o niepodległości państwowej ziem ukraińskich byłej monarchii austro-węgierskiej" ${ }^{69}$. Jeżeli wziąć pod uwagę wymiar prawny treści tego dokumentu oraz jego cechy formalne, to w istocie pełnił on rolę „małej konstytucji” (został podzielony na pięć artykułów, każdy był zatytułowany, a całość - ponumerowana). W ustawie została zatwierdzona nazwa nowego państwa - Zachodnioukraińska Republika Ludowa (art. I),

${ }^{66}$ O. Karpenko, Zachidno-Ukrajinśka Narodna Respublika. 1918-1923. Istorija, Iwano-Frankiwśk 2001, s. 89.

${ }^{67}$ K. Łewyćkyj, Wetykyj Zryw, Lwiw 1931, s. 112-114.

${ }^{68}$ Ukrajinśkyj Narode!, „Diło” 2 I 1918.

${ }^{69}$ Tymczasowyj osnownyj zakon pro derżawnu samostijnist' ukrajinśkych zemel bywszoji ajstro-uhorśkoji monarchiji, uchwatenyj Ukrajinśkoju Nacionalnoju Radoju na zasidanniu dla 13 padotysta 1918 r., „Diło”, 15 XI 1918. 
zakreślone jego terytorium - ukraińskie ziemie etniczne byłych Austro-Węgier (art. II i III) oraz sformułowana zasada prymatu prawa i suwerenności narodu, które miały być realizowane przez wybrane w sposób demokratyczny organy przedstawicielskie. Do czasu zwołania najwyższej instytucji władzy w państwie — Zgromadzenia Założycielskiego — pełnia władzy należała do Rady Narodowej (art. IV). Zatwierdzone również zostały główne symbole państwowości: godło (złoty lew na niebieskim tle), niebiesko-żółta flaga, pieczęć (art. V).

Między listopadem 1918 r. a czerwcem 1919 r. Rada Narodowa funkcjonowała jako najwyższy tymczasowy organ przedstawicielski ZURL. Zgodnie z liberalno-demokratyczną zasadą podziału władzy funkcje tego organu były związane z zapewnieniem reprezentacji interesów różnych warstw ludności, legislacją, tworzeniem organów państwowych oraz kontrolą działalności władzy wykonawczej, zapewnieniem przejrzystości polityki itp. Na to, w jaki sposób spełniała te funkcje, wpływ miały (też negatywny) m.in. relacje międzypartyjne w wewnętrznej scenie politycznej czy zmiana sytuacji na froncie polsko-ukraińskim, która zmuszała organy ZURL do przemieszczania się.

Niezależnie od warunków, w jakich działała, Rada Narodowa starała się stale poszerzać reprezentację interesów obywateli, czego wyrazem były zmiany w składzie, próby włączenia do udziału w jej pracach przedstawicieli mniejszości narodowych. W jej ewolucji można wyodrębnić dwa podstawowe etapy, ze względu na specyfikę struktury i skład członkowski ${ }^{70}$. Podczas pierwszego - „lwowskiego” (18 października-21 listopada 1918 r.) — była ona podzielona na trzy delegatury terytorialne (komisje, delegacje). Pierwsza - ogólna we Lwowie pod przewodnictwem Jewhena Petruszewicza — domagała się od austriackiego rządu prawomocnego przekazania władzy Ukraińcom. Druga — halicka we Lwowie na czele z K. Łewickim — rozpoczęła tworzenie struktur ukraińskiej władzy: powołała Centralne Biuro Rady Narodowej i Urząd Spożywczy; wezwała ludność ukraińską do niewykonywania rozporządzeń Polskiej Komisji Likwidacyjnej; legion Ukraińskich Strzelców Siczowych uznała za podstawę sił zbrojnych państwa ukraińskiego. Trzecia — bukowińska w Czerniowcach — nie miała uprawnień legislacyjnych, a jedynie reprezentowała ukraińskie interesy na terytorium okupowanym przez Rumunów. Nowo powołana Rada Narodowa liczyła 52 członków (26 posłów do wiedeńskiej Rady Państwa, 20 posłów na Sejm Galicyjski i Bukowiński, 4 członków Izby Panów, 2 dokooptowanych przedstawicieli partii politycznych). W związku z tym już w pierwszych tygodniach jej działań państwowotwórczych za ważne i potrzebne uznano uzupełnienie jej składu o delegatów z terenu, tak aby był on bardziej demokratyczny. W tym celu 15 listopada 1918 r. uchwalono ustawę o uzupełnieniu składu Ukraińskiej Rady Narodowej o delegatów reprezentujących powiaty oraz duże miasta kraju, w myśl której z każdego powiatu i z dziesięciu miast miał być wybrany jeden delegat, a także czterech ze Lwowa oraz po dwu z Czerniowiec i Stanisławowa ${ }^{71}$. Wybory

70 D. Janewśkyj, Polityczni systemy Ukrajiny 1917-1920 rokiw: sproby tworennia i pryczyny porazky, Kyjiw 2003, s. 270-272.

${ }^{71}$ Zachidno-Ukrajinśka Narodna Respublika 1918-1923. Dokumenty i materiaty, t. II, red. O. Karpenko, K. Mycan, Iwano-Frankiwśk 2001, s. 15-16. 
zorganizowane przez komisarzy powiatowych, w których wzięły udział lokalne organizacje polityczne, kulturalno-oświatowe i gospodarcze, odbyły się w dniach 22-26 listopada $\mathrm{w}$ większości powiatów i w miastach wskazanych w ustawie. $\mathrm{W}$ ich rezultacie liczebność Rady Narodowej wzrosła do 82 członków.

Podczas drugiego „okresu stanisławowskiego” (styczeń-maj 1919 r.) po kolejnym dokooptowaniu członków liczebność Rady Narodowej wynosiła już 123 deputowanych. Uściślając powyższą liczbę należałoby przyjąć, że ogółem liczyła ona 195 członków, ponieważ liczba delegatów uczestniczących w pracy poszczególnych delegacji i uczestniczących w posiedzeniach nie pokrywała się z oficjalnymi danymi. Co do reprezentowanych w niej zawodów, to w Radzie Narodowej najliczniejsi byli prawnicy (55), a następnie: nauczyciele (43), chłopi (27), duchowieństwo (24), zasiadali w niej również urzędnicy (9), dziennikarze (7), kolejarze (6), inżynierowie i studenci (po 4), przedstawiciele inteligencji twórczej i naukowcy. Jeżeli brać pod uwagę status społeczny (dane dla 124 osób), to 45 członków Rady pochodziło z rodzin księżowskich, 37 - z chłopskich, 17 - z nauczycielskich, 10 - mieszczan i rzemieślników, 6 - urzędników i in. Większość deputowanych miała od 30 do 50 lat, byli to ludzie o stabilnej sytuacji finansowej oraz mobilni ${ }^{72}$.

Delegatów Rady Narodowej wiążą z tradycjami austriackiego parlamentaryzmu trzy ważne okoliczności: 1) 1/3 jej składu stanowili byli posłowie do parlamentu wiedeńskiego i Sejmu Krajowego; 2) tylko dwie kobiety wchodziły w skład delegacji bukowińskiej; 3) wysoki poziom wykształcenia: 36\% członków miało średnie wykształcenie, 42\% — wyższe; wśród nich 52 — stopień doktora, głównie praw (35), filozofii (10). W parlamentarnym gremium znaleźli się również znani literaci: Wasyl Stefanyk, A. Kruszelnicki, P. Karmański; uczeni i profesorowie akademiccy: O. Barwiński, S. Dnistriański, M. Korduba, K. Studyński; prawnicy — S. Hołubowicz, R. Parfecki; hierarchowie - metropolita A. Szeptycki, trzej biskupi oraz księża A. Bandera, S. Onyszkewicz. Nie zostały zrealizowane postulaty organizacji kobiecych o włączenie do Rady Narodowej ich przedstawicielek ${ }^{73}$.

Jednak aby zoptymalizować funkcjonowanie Rady Narodowej, zostały podjęte kompleksowe, chociaż niezbyt aktywne działania zmierzające do udoskonalenia jej struktury wewnętrznej. Dopiero 4 stycznia 1919 r. na mocy przyjętej ustawy zostało powołane stałe Prezydium, w skład którego wchodzili prezydent (J. Petruszewicz) oraz czterech jego zastępców (Ł. Baczyński, O. Popowicz, S. Wityk, A. Szmihelski), powierzono mu zadania o charakterze organizacyjnym oraz prowadzenie posiedzeń. Sprawami administracyjnymi miał się zajmować Sekretariat, pracowali w nim dwaj sekretarze (O. Ustyjanowicz, S. Wytwicki) oraz ich zastępcy. Również wówczas, na mocy jeszcze innej ustawy, na ogólnym zebraniu został wybrany 10-osobowy Wydział Rady Narodowej,

72 O. Pawłyszyn, Ukrajinśka Nacionalna Rada ZUNR-ZOUNR: rekonstrukcija osobowoho składu (żowteń 1918 r. - czerweń 1919 r.), [w:] Materiały zasidań Istorycznoji ta Archeohraficznoji komisij NTSz w Ukrajini. Bun. другий (1995-1997 r.), Lwiw 1999, s. 250-252.

73 Vide O. Pawłyszyn, Socialno-politycznyj portret ukrajinśkoho prowodu Hatyczyny ta Bukowyny w rewoluciji 1918-1919 rokiw, „Ukrajina Moderna” 2000, z. 4-5, s. 187-245. 
którego przewodniczącym został J. Petruszewicz. Uprawnienia tego urzędu były tak rozległe, że wymaga to dokładniejszego przedstawienia jego istoty. Wydział miał ,zastępować" (pełnić obowiązki) przejściowo (do czasu zjednoczenia) głowę państwa, Referent komisji legislacyjnej T. Okunewski objaśniając zapisy ustawy utrzymywał, że jego powołanie zagwarantowało demokratyczny podział władzy: „władza ustawodawcza w rękach rady, władza wykonawcza w rękach rządu. Dla Wydziału zostawiliśmy suwerenne prawa [...]. Do kompetencji Wydziału Rady Narodowej należy: desygnowanie oraz przyjęcie dymisji sekretariatu państwa, amnestia i abolicja, sprawdzenie i ogłoszenie ustaw oraz reprezentowanie na zewnątrz" " Zatem de facto ów kolegialny organ pełnił funkcje głowy państwa.

Warianty aktów legislacyjnych Rady Narodowej, zwłaszcza ustawy o Wydziale Rady Narodowej, prowadziły do wykrzywionej interpretacji w literaturze naukowej uprawnień różnych instytucji struktur władzy. Mianowicie nazywanie J. Petruszewicza „prezydentem Rady Narodowej” nie oznacza, że w ZURL-ZOURL istniał urząd prezydenta w rozumieniu (z uprawnieniami) szefa państwa. Petruszewicz faktycznie pełnił obowiązki przewodniczącego (spikera) parlamentu, zaś Wydział Rady Narodowej miał uprawnienia, które pod wieloma względami pokrywały się z uprawnieniami prezydenta jako głowy państwa. Zgodnie z ustawą o sposobie ogłoszenia dokumentów legislacyjnych Rady Narodowej miały być one publikowane po podpisaniu przez prezydenta (przewodniczącego) J. Petruszewicza oraz jednego z członków Wydziału Rady Narodowej.

Pod względem formy sprawowania władzy ZURL-ZOURL stanowiła republikę, której ustrój ewoluował od parlamentarnego w kierunku parlamentarno-prezydenckim. W myśl pierwszych dokumentów legislacyjnych Rada Narodowa formowała rząd na bazie międzypartyjnej i był on jej podporządkowany jako najwyższemu organowi prawodawczemu. $Z$ czasem wewnątrz Rady powstał Wydział, de facto nowy ośrodek władzy wyposażony w uprawnienia właściwe dla urzędu prezydenckiego: desygnowanie i dymisja rządu, ogłoszenie amnestii, mianowanie najwyższych urzędników państwowych, zatwierdzanie ustaw. Rada Narodowa, odwołując się do praktyki parlamentaryzmu europejskiego, przyznała swoim członkom immunitet. W specjalnym dokumencie stwierdzono, że bez zgody Rady nie mogą oni zostać pociągnięci „,do odpowiedzialności sądowej” nawet wówczas, gdy zostaną zatrzymani na miejscu przestępstwa. Zostali oni też zwolnieni z odpowiedzialności „za to czy inne głosowanie” oraz mieli wypełniać swoje obowiązki „niezależnie od jakichkolwiek instrukcji wyborców”75. O działalności Rady Narodowej i jej priorytetach wiele mówią działające w jej ramach komisje, koordynujące poszczególne odcinki pracy. Fakt, że często zmieniała się ich liczba, skład, szefowie był spowodowany niestabilną sytuacją wojskowo-polityczną oraz międzynarodową. Po kilku restrukturyzacjach na posiedzeniu Rady Narodowej 4 stycznia 1919 r. zostały powołane komisje: spraw zagranicznych (przewodniczący

${ }^{74}$ Druha sesija Ukr. Nacionalnoji Rady, „Nowe Żyttia” 2 II 1919.

${ }^{75}$ Zakon z dnia 4 sicznia 1919 r. pro Wydit UN Rady, ,Wisnyk Derżawnych Zakoniw i Rozporiadkiw Zachidnoji Obłasti Ukrajinśkoji Narodnoji Respubliky”, 31 I 1919, wyp. 1. 
S. Wityk, 19 członków, według moich danych); legislacyjna (L. Łewycki, 16 członków); finansowa (S. Wityk, 12 członków); wojskowa (O. Wesołowski, 20 członków); opieki społecznej (Ł. Baczyński, 12 członków); ziemska (S. Danyłowicz, 15 członków); szkolna (A. Ałyśkewicz, 14 członków); odbudowy technicznej (I. Popowicz, 9 członków); komunikacyjna (T. Okunewski, 7 członków). Komisje te de facto działały do czerwca $1919 \mathrm{r}^{76}$

W swoich odezwach i dokumentach Rada Narodowa nazywała siebie „ukraińskim parlamentem". Ponieważ organ ten nie został wybrany w wyborach powszechnych jak parlamenty w krajach zachodnich, to jest to określenie umowne. Z okoliczności tej zdawali sobie sprawę sami przywódcy Rady, gdyż już w pierwszych jej odezwach i w „Tymczasowej ustawie zasadniczej” była mowa wyłonieniu w wyborach powszechnych Zgromadzenia Ustawodawczego jako najwyższego organu prawodawczego ZURL. M. Czubatyj w swoich wspomnieniach zauważył, że chociaż Rada Narodowa „została uzupełniona przez świeże siły ze wszystkich stron kraju, sama ona najlepiej czuła, że nie jest sejmem, wybranym w głosowaniu powszechnym, dlatego pracując nad przyjęciem wielce potrzebnych ustaw, robiła wszystko, ażeby jak najszybciej ustąpić miejsca nowo wybranemu sejmowi" "77.

W takich okolicznościach, dzięki „,sprawnej pracy różnych partii” oraz po przygotowaniach, dyskusjach i omówieniach na sesji Rady Narodowej, 15 kwietnia 1919 r. została przyjęta ustawa o zwołaniu Sejmu ZOURL oraz o wyborach (ordynacji wyborczej) do Sejmu ZOURL ${ }^{78}$. Zgodnie z ich zapisami, najwyższym organem władzy ustawodawczej miał być jednoizbowy sejm (parlament), wyłoniony na podstawie kryteriów narodowościowych: na ogólną liczbę 226 miejsc - 160 zostało przyznanych przedstawicielom narodowości ukraińskiej, 33 - polskiej, 27 - żydowskiej, 6 - niemieckiej. Mieli oni zostać wybrani na podstawie ,powszechnego równego bez różnicy płci, tajnego, bezpośredniego i proporcjonalnego prawa wyborczego". Prawo głosowania przyznano obywatelom, którzy ukończyli 21 lat, zaś prawo kandydowania -25 lat. Termin wyborów nie został wyznaczony, niemniej ustalono, że Rada Narodowa przekaże swoje uprawnienia nowo wybranemu parlamentowi na jego pierwszym posiedzeniu, które zostanie zwołane przez prezesa Rady nie później niż w ciągu 14 dni po ogłoszeniu wyników głosowania przez komisję wyborczą. Jej przewodniczący orzekał o zgodności z prawem procesu wyborczego oraz prawomocności wyboru każdego posła.

Prawnie pozbawieni praw wyborczych zostali „chorzy psychicznie”, skazani za przestępstwa kryminalne, za przestępstwa ,przeciw swobodzie wyborczej”, „za pijaństwo". W związku z zaplanowanymi wyborami miały zostać utworzone okręgi wyborcze (odpowiadające jednej bądź kilku dużym gromadom). Partie, które zamierzały wziąć udział w wyborach, miały dostarczyć okręgowym komisjom wyborczym zatwier-

${ }^{76}$ Komisiji Ukrajinśkoji Nac. Rady wybrani na zasidanniu 2 i 4 sicznia, „Nowe Żyttia”, 7 I 1919.

${ }_{77}$ M. Czubatyj, Derżawnyj ład na Zachidnij Obłasty Ukrajinśkoji Narodnioji Respubłyky, Lwiw 1921, s. 14.

${ }^{78}$ Centralnyj derżawnyj istorycznyj archiw Ukrajiny u Lwowi, ф. 581, оп. 1, спр. 96, арк. 15-16. 
dzone przez co najmniej 100 wyborców listy swoich kandydatów. Ściśle uregulowany został tryb zgłaszania i rejestrowania kandydatów na deputowanych, tworzenia list do głosowania, przeprowadzenia wyborów, liczenia głosów, ogłoszenia wyników. Szerokie uprawnienia przyznano „mężom zaufania” (mieli nimi być przedstawiciele organizacji społecznych i partii, a ich status był zbliżony do statusu współczesnych obserwatorów wyborczych) - mogli oni śledzić przebieg wyborów, liczenie głosów, zatwierdzanie wyników głosowania.

Wybory miały odbyć się w czerwcu 1919 r., ale na przeszkodzie im stanęły wydarzenia na froncie polsko-ukraińskim. Jednak można uznać, że tworzenie najwyższych instytucji władzy przedstawicielskiej ZURL (w praktyce i w zamierzeniach) przebiegało w sposób demokratyczny, było zorientowane na utrwalenie zasad demokracji, zagwarantowanie praw wyborczych i swobód obywateli bez względu na przynależność narodową, status społeczny, wyznanie czy wyznawane poglądy. Z ówczesnej europejskiej praktyki legislacyjnej został zapożyczony mechanizm realizacji praw wyborczych mniejszości narodowych w poszczególnych okręgach, tworzonych na podstawie kryterium narodowościowego: ukraińskich (15), polskich i żydowskich (po 5), niemiecki $(1)^{79}$. Ponieważ nie udało się powołać pełnowartościowego sejmu, do końca istnienia ZURL funkcje najwyższego przedstawicielskiego organu legislacyjnego pełniła Rada Narodowa, której legalność i prawomocność jest bezsporna.

Rada Narodowa, jako najważniejszy organ przedstawicielski konsekwentnie wypełniała przypisane jej funkcje ustawodawcze. Jednak w warunkach wojny i rewolucji nie wszystkie przyjęte przez nią dokumenty prawne udało się wprowadzić w życie. Podstawy jej działalności określała ustawa o tymczasowej administracji obwodów Zachodnioukraińskiej Republiki Ludowej z 16 listopada 1918 r., zgodnie z którą na obszarze ZURL w dalszym ciągu obowiązywało wcześniejsze prawo austriackie, jeżeli nie było sprzeczne z interesami państwa ukraińskiego (pkt 1). Powyższy przepis jest przedmiotem dyskusji wśród badaczy różnych nurtów ideowych, którzy zarzucają Radzie „konserwatyzm”, „niezdolność (słabość) do tworzenia własnego ustawodawstwa”, czy wręcz „reakcyjność”. Niemniej, jeżeli wziąć pod uwagę ówczesną sytuację, po części można się zgodzić z M. Stachowem, który dowodzi, że ZURL ,chciała być państwem rządów prawa”, ponieważ „uchwalenie nowego oryginalnego prawa w krótkim czasie nie było możliwe, nadal musiały obowiązywać stare akty prawne, tak aby nie powstał chaos", jednak miały one „podlegać stopniowej zmianie bądź zamianie" ${ }^{80}$. Równocześnie należy uwzględniać aspekt austrofilstwa, czyli warunki, w jakich uformowała się ukraińska scena polityczna i jakie były w niej reprezentowane orientacje ideologiczne, np. Ukraińska Centralna Rada czy Dyrektoria w Ukrainie Naddnieprzańskiej w ogóle nie zważała na stare prawo imperialne.

Przywódcy ZURL-ZOURL starali się stworzyć pełnowartościową bazę prawną umożliwiającą reformowanie wszystkich sfer życia społecznego. Pod względem priory-

${ }^{79}$ M. Czubatyj, Derżawnyj ład na Zachidnij Obłasty Ukrajinśkoji Narodnioji Respubłyky..., s. 34.

${ }^{80}$ M. Stachiw, Zachidnia Ukrajina. Narys istoriji derżawnoho budiwnyctwa ta zbrojnoji i dyptomatycznoji oborony w 1918-1923, t. IV, Skrenton 1962, s. 53. 
tetów podsystem regulacyjny (normatywny) jej systemu politycznego można podzielić na „bloki” norm prawa narodowego, które regulowały funkcjonowanie takich obszarów jak: władza polityczna i administracyjna; zdolność do obrony, stabilność społeczno-ekonomiczna; bezpieczeństwo wewnętrzne i przestrzeganie prawa; demokratyczne prawa i swobody obywateli, zwłaszcza mniejszości narodowych; polityka zagraniczna; rozwój narodowy i kulturalny.

Rada Narodowa, opierając się na starych austriackich normach prawnych i austriackiej praktyce zdecydowanie i konsekwentnie na tyle, na ile umożliwiał to stan wojny, starała się stworzyć bazę prawną do tworzenia pionu władzy wykonawczej. W szczególności uchwaliła niemal 20 dokumentów, które określiły treść, strukturę, funkcje oraz uprawnienia rządu centralnego oraz organów władzy lokalnej i administracji. Początkowo, w listopadzie 1918 r., miały one charakter „tymczasowy”, lecz „modernizowane” w styczniu-kwietniu 1919 r. ustawy przyjmowano już na długo. Rada Narodowa dała interesujący i unikatowy nie tylko w wymiarze narodowym, ale też ogólnoeuropejskim przykład przystosowania w krótkim czasie monarchicznej bazy legislacyjno-prawnej (która zasadniczo spełniała normy czołowych demokracji w Europie) do republikańskiego systemu rządzenia w ZURL. W pełni odnosi się to również do legislacji, która regulowała wiele kwestii związanych z zapewnieniem bezpieczeństwa wewnętrznego i porządku prawnego czy przyznania demokratycznych praw i swobód obywatelom, w tym przedstawicielom mniejszości. Do czasu powołania rządu Rada Narodowa pełniła nie tylko funkcje ideowo-mobilizacyjne, ale także decyzyjne i organizacyjne, związane z zapewnieniem zdolności obronnej ZURL. Już w dniach 1-6 listopada 1918 r. wydała wiele odezw do ukraińskich żołnierzy i oficerów dawnej austriackiej armii i ludności cywilnej, w których wzywała, aby z bronią w ręku stanęli w obronie własnego ukraińskiego państwa. W odezwie „Ukraińscy żołnierze” i „Do broni!” odwołano się do doktryny państwowej i politycznej, w myśl której każdy naród ma suwerenne prawo stać się „wolnym i równym, gospodarzem na swojej ziemi!" i aby społeczność ukraińska wywalczyła wolność i prawo do samookreślenia, musi „przede wszystkim mieć swoje wojsko" ${ }^{81}$. W tym okresie Rada bezpośrednio mianowała najwyższych dowódców wojskowych. Po przekazaniu funkcji organizacyjnych i decyzyjnych w zakresie formowania sił zbrojnych i dowodzenia właściwemu ministerstwu, Rada Narodowa wydawała dokumenty prawne dotyczące mobilizacji wojskowej oraz wsparcia socjalnego żołnierzy oraz ich rodzin ${ }^{82}$.

Najtrudniejszy segment w działalności legislacyjnej Rady Narodowej stanowił blok ekonomiczny, w którym ujawniały się nie tylko wewnętrzne sprzeczności polityczne, ale do pewnego stopnia również różne opcje w sferze polityki zagranicznej. Chodzi tu przede wszystkim o sprawę reformy ziemi, w której najpełniej uwidoczniła się ewolucja parlamentaryzmu oraz stan i perspektywy rozwoju społeczeństwa obywatelskiego w ZURL-ZOURL w ogóle. Kwestia ta była omawiana na forum Rady Narodowej

\footnotetext{
${ }^{81}$ Pid orużżia!, „Diło” 6 XI 1918.

${ }^{82}$ Ukrajinśki wojaky!, ibidem.
} 
w burzliwych dyskusjach od początku do końca jej istnienia. W celu przygotowania projektu reformy agrarnej na pierwszych posiedzeniach Rady w dniach 2-4 stycznia $1919 \mathrm{r}$. w Stanisławowie została wybrana międzypartyjna komisja ziemska z udziałem fachowców, jej przewodniczący i skład się kilkukrotnie zmieniali. Ustawa ziemska została uchwalona 14 kwietnia 1919 r. - miała charakter kompromisowy i nie rozstrzygała wszystkich istotnych kwestii ${ }^{83}$. Stosunkowo dhugo trwało wprowadzanie do dokumentów prawnych obietnic socjalnych, złożonych przez Radę Narodową w odezwach programowych z 1 i 5 listopada 1918 r. Odnosi się to także do przyjętej dopiero 12 kwietnia 1919 r. ustawy o wprowadzeniu ośmiogodzinnego dnia pracy dla robotników ${ }^{84}$.

Rada Narodowa jako uznany najwyższy organ przedstawicielski władzy państwowej $\mathrm{w}$ pełni realizowała swoje uprawnienia $\mathrm{w}$ zakresie utworzenia bazy prawnej w dziedzinie relacji międzynarodowych, które przy wszystkich sprzecznościach i trudnościach ewoluowały w dwóch podstawowych kierunkach — zjednoczenia ziem ukraińskich i zachodnioeuropejskim. Dokumentem o wielkiej wadze politycznej była uchwała z 3 stycznia 1919 r. o zjednoczeniu ZURL i URL, proklamująca ich połączenie w ,jedną suwerenną Republikę Ludową" oraz powierzająca rządowi ZURL przeprowadzenie rozmów z rządem kijowskim dla realizacji „umowy przedwstępnej” z 1 grudnia 1918 r. Do czasu zwołania Zgromadzenia Ustawodawczego zjednoczonej Republiki władza ustawodawcza na obszarze „byłej” ZURL miała się znajdować w rękach Rady Narodowej ${ }^{85}$. Duże znaczenie w tej dziedzinie miały ustawy o wprowadzeniu obywatelstwa URL oraz hrywien i karbowańców URL na terenie ZOURL ${ }^{86}$.

Charakter legislacji ukierunkowany narodowo uwypuklają akty prawne dotyczące rozwoju oświaty i kultury. Najważniejsze spośród nich zostały uchwalone w lutym 1919 r.: ustawa o podstawach szkolnictwa (wszystkie szkoły publiczne na obszarze ZOURL zostały uznane za państwowe, nauczyciele stali się urzędnikami państwowymi, językiem nauczania miał być ukraiński), o przyznaniu statusu państwowego ukraińskim prywatnym gimnazjom i seminariom nauczycielskim. Na mocy ustawy językowej, ukraiński uzyskał status języka państwowego (obowiązywał w placówkach i instytucjach państwowych), zaś mniejszościom narodowym przyznano prawo posługiwania się językiem ojczystym w kontaktach prywatnych oraz w relacjach z przedstawicielami oficjalnych władz i instytucji publicznych ${ }^{87}$. Na poziomie ustawodawczym były rozstrzygane m.in. tego rodzaju „sprawy bieżące”, jak zmiany w procedurach egzaminacyjnych w szkołach średnich, wysokość wynagrodzenia nauczycieli oraz inne, zazwyczaj znajdujące się w gestii rządu ${ }^{88}$. Duży akcent kładziono na rozwój edukacji, co było

${ }^{83}$ Komisiji Ukrajinśkoji Nac. Rady wybrani na zasidanniu 2 i 4 sicznia, „Nowe Żyttia”, 7 I 1919.

${ }^{84}$ Zachidno-Ukrajinśka Narodna Respublika 1918-1923, Dokumenty i materiały..., t. II, s. 344-345.

${ }^{85}$ Uchwała Ukrajinśkoji Nacionalnoji Rady z dnia 3 sicznia 1919 r. pro Złuku Zachidnio-Ukrajinśkoji Narodnoji Respubliky z Ukrajinśkoju Narodnioju Respublikoju, ,Wisnyk derżawnych zakoniw i rozporiadkiw Zachidnoji Obłasty Ukrajinśkoji Narodnoji Respubliky”, 31 I 1919, z. 1.

${ }_{86}$ Zachidno-Ukrajinśka Narodna Respublika, 1918-1923, Dokumenty i materiaty..., t. II, s. 331-332, $335-337$.

${ }^{87}$ Ibidem, s. 220-221, 222, 226.

${ }^{88}$ Ibidem, s. 228-229. 
uwarunkowane tradycjami walki narodowowyzwoleńczej, gdzie jedną z fundamentalnych idei stanowiła narodowa szkoła. Natomiast inne obszary sfery kultury nie należały do priorytetowych w związku ze zniszczeniami wojennymi.

Ukraińska Rada Narodowa zajmowała się również polityką zagraniczną: wysyłała noty i telegramy do rządów innych państw i instytucji, zatwierdzała skład delegacji i udzielane im pełnomocnictwa w zakresie negocjacji z innymi krajami i zawierania porozumień. Z jednej strony prowadziła rozmowy z rządem P. Skoropadskiego oraz pogłębiła relacje z Dyrektorią, czego zwieńczeniem było zjednoczenie URL i ZURL, chociaż z powodu różnych uwarunkowań wewnętrznych i zewnętrznych nie zostało ono sfinalizowane ${ }^{89}$. Z drugiej strony prowadziła negocjacje z krajami europejskimi, które miały doprowadzić do uznania przez nie ukraińskiej państwowości. One także nie przyniosły oczekiwanych rezultatów. Rada Narodowa i rząd ZURL-ZOURL opracowali i konsekwentnie realizowali strategię polityki zagranicznej, która leżała w interesach narodu ukraińskiego i broniła jego prawa do suwerenności i niepodległości. Rada Narodowa jako najwyższy przedstawicielski organ prawodawczy powoływała rząd i inne organy władzy wykonawczej oraz sprawowała nad nimi kontrolę. Chociaż nie znaleziono żadnych dokumentów bezpośrednio regulujących relacje między nimi, to wiele o ich istocie i mechanizmach możemy się dowiedzieć z dokumentów prawnych, raportów i stenogramów z posiedzeń parlamentu. Rada Narodowa powołała i odebrała przysięgę od pierwszego rządu ZURL, przyjmowała dymisje jego członków, a następnie dymisję całego rządu oraz powołała drugi gabinet, który funkcjonował do końca republiki. To również ona powołała prokuratora generalnego oraz innych wysokiej rangi urzędników. Mimo że do czasu powołania rządu Rada Narodowa pełniła funkcje decyzyjno-wykonawcze, to w tym okresie funkcjonował mniej więcej jasny podział kompetencji między władzą ustawodawczą a wykonawczą, przy czym znaczenie tej drugiej stale rosło (co było uwarunkowane regułami procesu politycznego i sytuacją stanu wojny). Ministrowie brali udział w pracach Rady Narodowej oraz w imieniu rządu występowali z inicjatywami ustawodawczymi. To właśnie z ich inicjatywy parlamentarzyści omówili i przegłosowali projekty ustaw, m.in. w sprawie rozszerzenia składu Rady Narodowej o przedstawicieli powiatów i miast czy wyborów do konstytuanty. Na początku drugiej sesji parlamentarnej w Stanisławowie 4 stycznia 1919 r. rząd zgłosił pakiet ponad 10 projektów ustaw, które dotyczyły aktualnych spraw społecznych: odbudowy zniszczonych domów, udzielenia pomocy nauczycielom i innym grupom ludności, ustanowienia języka państwowego, ograniczenia handlu tytoniem i jego konsumpcji itp. Większość z nich została uchwalona ${ }^{90}$.

W okresie „stanisławowskim” ZURL uwaga Rady Narodowej skupiała się na wysłuchiwaniu i omawianiu sprawozdań poszczególnych ministrów oraz krytyce ich pracy, której podłożem często były różnice partyjne (zostały omówione w dalszej części niniej-

${ }^{89}$ O. Karpenko, Zachidno-Ukrajinśka Narodna Respublika 1918-1923. Istorija, Iwano-Frankiwśk 2001, s. 377, 437.

90 Vide Zachidno-Ukrajinśka Narodna Respublika 1918-1923, Dokumenty i materiaty..., t. II, s. 176-183. 
szego artykułu). Drugiej sesji rady towarzyszyły burzliwe dyskusje m.in. na temat przeprowadzania rekwizycji mienia wśród ludności, celowości wprowadzenia stanu wyjątkowego na wsi, sytuacji w przemyśle naftowym, reorganizacji szkolnictwa, reformy rolnej oraz wielu innych. Wiele projektów ustaw przyjęto w drugim bądź trzecim czytaniu ${ }^{91}$.

Działająca w warunkach wojny i rewolucji Rada Narodowa zajmowała się również kwestią informowania obywateli o sprawach stanowiących przedmiot bieżącej polityki publicznej. Wyrazem tego było uchwalenie ustawy o sposobach ogłaszania ustaw i rozporządzeń. Zgodnie z jej przepisami wszystkie ustawy z podpisem prezydenta Rady i jednego z członków Wydziału oraz rozporządzenia z podpisem sekretarza miały być publikowane w „Dzienniku Ustaw Państwowych i Rozporządzeń Zachodniego Obwodu Ukraińskiej Republiki Ludowej"’2. Każdy dokument legislacyjny powinien zawierać datę uchwalenia ustawy, zaś wchodził w życie osiem dni po publikacji. Pierwszy numer „Dziennika Ustaw” ukazał się 31 stycznia 1919 r., w sumie wydano 10 numerów.

Prasa, i to nie tylko „centralna” (czasopisma „Diło”, „Nowe Żyttia”, „Republika” wychodziły w Stanisławowie), ale także lokalne tytuły („Pokutśkyj Wistnyk” w Kołomyi, „Towmaćki Wisty”, „Drohobyćkyj Łystok”, „Hołos Podillia” w Tarnopolu) obszernie opisywała przebieg debat parlamentarnych. Dzięki temu szerokie warstwy społeczeństwa mogły włączyć się do dyskusji na temat problemów polityki publicznej, poznać stanowisko różnych sił politycznych, alternatywne projekty ustaw, zwłaszcza dotyczących reformy rolnej itp. W jakiejś mierze obywatele stali się współuczestnikami systemu rządzenia państwem, zwiększyła się odpowiedzialność polityków i parlamentarzystów za podejmowane działania. Szczególną wartością pracy Rady Narodowej był jej ścisły kontakt $\mathrm{z}$ władzami lokalnymi, słuchanie głosu szerokiej opinii publicznej, analizowanie i uwzględnianie jej postulatów. Na posiedzeniach Rady były również przedstawiane propozycje poszczególnych gromad, jak również komisarzy powiatowych oraz przedstawicieli rad powiatowych i gromadzkich.

Równolegle z rozwojem tymczasowego najwyższego organu prawodawczego w listopadzie i grudniu 1918 r. powstały terenowe organy przedstawicielskie — powiatowe Ukraińskie Rady Narodowe. Rady te miały zastąpić rady powiatowe działające w czasach Austro-Węgier, liczyły 26 członków wybranych w systemie kurialnym, kierował nimi organ kolegialny - Wydział, na którego czele stał marszałek. Rady te miały spore uprawnienia i były niezależne od państwowych organów władzy wykonawczej, co prowadziło do pewnej „dwuwładzy”, a niekiedy również konfliktów między nimi. Taka sytuacja nie odpowiadała organom władzy centralnej, ponieważ w warunkach wojny i rewolucji konieczne było szybkie uchwalanie rozporządzeń i wprowadzanie ich w życie. Dlatego w początkowym okresie nie rozważano powoływania powiatowych Rad Narodowych jako organów samorządowych, ponadto ich status nie był uregulowany, możliwości zaś ograniczone, a sprowadzały się one do pełnienia funkcji doradczych przy komisarzach powiatowych. Potwierdza to ustawa o tymczasowej

\footnotetext{
91 Druha sesija Ukr. Nacionalnoji Rady, „Nowe Żyttia” 1919, 7.02, 13.02, 18.02.

92 Zachidno-Ukrajinśka Narodna Respublika 1918-1923, Dokumenty i materiaty..., t. II, s 154.
} 
administracji z 16 listopada 1918 r. ${ }^{93}$, która określiła zakres kompetencji pionu wykonawczego ZURL. W myśl tej ustawy obywatele ZURL w powszechnym głosowania wybierali rady powiatowe, a w gromadach i miastach — rady gromadzkie i miejskie. W ten sposób ich „godni zaufania przedstawiciele” mieli pozbawić polską szlachtę przywilejów, które zostały jej przyznane w czasach monarchii. Niektóre powiatowe Rady Narodowe powstały w ostatniej dekadzie października 1918 r. (Dolina, Drohobycz, Sokal, Przemyśl, Podhajce, Stanisławów), niemniej proces ich powoływania przeciągnął się do listopada-grudnia $1918 \mathrm{r}$. i nigdy nie uzyskał precyzyjnych ram organizacyjnych. Ponadto rady nie powstały we wszystkich miejscowościach ${ }^{94}$. Centralne kierownictwo polityczne zrezygnowało z powielania austriackiego modelu samorządowego, a działalności samorządu nie regulowały odrębne przepisy, lecz rozporządzenia rządu dotyczące władz wykonawczych w terenie.

W takich okolicznościach instytucjonalizacja samorządu przybierała różne formy organizacyjne jak rady doradcze, komitety powiatowe, Rady Narodowe. Na początku rady powstawały na bazie lokalnych ośrodków UNDP Ukraińskiej Partii Narodowo-Ludowo-Demokratycznej oraz organizacji kulturalno-oświatowych, z czasem wstępowali do nich członkowie różnych partii politycznych, przedstawiciele lokalnej władzy wykonawczej i różnych warstw społecznych. W taki też sposób powstała Powiatowa Rada Gospodarcza w Stanisławowie, wybrana w wyborach powszechnych. Do Komitetu Powiatowego w Buczaczu weszli przedstawiciele pięciu okręgów, na które to miasto zostało podzielone. W wyniku łączenia rad powiatowych i miejskich powstały okręgowe Rady Narodowe jako wspólne organy przedstawicielskie powiatów, np. Kołomyi i Peczeniżyna, gdzie do powstałego w wyniku ich połączenia okręgu weszli delegaci gromad wiejskich i ukraińskich organizacji z tych miast. W Kałuszu organ przedstawicielski został utworzony jeszcze w październiku 1918 r., później otrzymał nazwę „Mała Rada”, podejmował decyzje dotyczące bieżących problemów miasta. Po dołączeniu do niej przedstawicieli gromad wiejskich powstała Szersza Rada, która zbierała się dwa razy w miesiącu, by dokonać przeglądu sytuacji w całym powiecie. Podobna powiatowa Szersza Rada, w której zasiadali przedstawiciele gromad wiejskich, funkcjonowała w Drohobyczu. Został również opracowany projekt utworzenia Powiatowej Wiejskiej Rady Ziemi Towmackiej [Tłumackiej], w skład której miało wejść 45 delegatów wybranych spośród chłopów, przedstawicieli organizacji gospodarczych i mniejszości narodowych ${ }^{95}$.

Powiatowe Rady Narodowe stały się ogólnonarodowymi organami przedstawicielskimi, reprezentującymi interesy różnych warstw społecznych. Liczyły one od 12 do 30 lub więcej członków, ich skład się zmieniał wraz z rozwojem sytuacji. Bezpośrednio po przewrocie $\mathrm{w}$ wielu radach ważną rolę odgrywali wojskowi, stanowiący wówczas nawet połowę ich składu. Na ogół na czele rad stali przedstawiciele inteligencji, która

93 Ustawa z dnia 16 listopada 1918 r. o tymczasowej administracji obwodów Zachodnioukraińskiej Republiki Ludowej, „Zbirnyk zakoniw, rozporiadkiw ta obiżnykiw, prohołoszenych Derżawnym Sekretariatom Zachodno-Ukrainśkoki Narodnoji Respubliky", 1918, s. 5-7.

94 M. Czubatyj, Derżawnyj ład na Zachidnij Obłasty Ukrajinśkoji Narodnioji Respubłyky..., s. 27.

95 Ibidem, s. 26-27. 
tradycyjnie odgrywała ważną rolę $\mathrm{w}$ działalności organizacji politycznych i kulturalno-społecznych. Moralny autorytet rad podnosił udział w nich księży greckokatolickich, którzy praktycznie byli członkami każdej powiatowej Rady Narodowej i często im przewodniczyli. Przedstawiciele chłopów (zwykle po dwóch, trzech delegatów) byli wybierani na zebraniach i zgromadzeniach (wiczach) w gromadach powiatu.

Tradycje samorządowe oraz ,inicjatywa lokalna” podniosły w czasach ZURL autorytet lokalnych organów przedstawicielskich. Zadania i strukturę rad częściowo regulowały instrukcje Rady Narodowej i rządu, ale generalnie nie wykształcił się jeden określony ich typ. Zasady funkcjonowania wielu powiatowych Rad Narodowych wyznaczały organy kolegialne — prezydium lub zarząd, które na wzór Lwowskiej Delegacji Rady Narodowej często składały się z przewodniczącego, sekretarza oraz ich zastępców. Aby rozwiązać szczególnie istotne kwestie, rady powoływały — w zależności od priorytetów w swojej działalności - specjalne komisje (np. wojskowe, ds. wyżywienia, finansowe, organizacyjne, sanitarne). Jeszcze jedną ich formę stanowiły referentury, odpowiadające strukturze rządu i powielające nazwy poszczególnych ministerstw ${ }^{96}$.

W wielu miejscowościach rady otrzymały szerokie kompetencje, a nawet decydujący głos w rozwiązywaniu różnych problemów społecznych za sprawą swego kierownictwa. Przykład takiej rady stanowi Drohobycka Powiatowa Rada Narodowa, której przewodniczył skompromitowany S. Wityk (były ambasador parlamentu wiedeńskiego, socjalista), jednocześnie szef Komisji Naftowej, którą została później przekształcona w Państwowy Komitet Naftowy. Aby ograniczyć wpływy tego „lokalnego dyktatora” na powiatowego komisarza Drohobycza, wyznaczono cieszącego się dużym autorytetem A. Horbaczewskiego. Powiatowe Rady Narodowe niekiedy powielały lub nawet przejmowały funkcje komisarzy powiatowych. Z tych względów M. Stachiw uznał ten „typ” organów władzy za „pośredni między organizacją państwową a autonomiczną"97.

Logicznym zwieńczeniem ewolucji powiatowych rad narodowych było przyznanie im funkcji pełnoprawnych organów władzy municypalnej. Powyższe zmiany zapoczątkowała przeprowadzona na grudniowym zjeździe komisarzy powiatowych w Stanisławowie w 1918 r. dyskusja na temat zakresu i rozgraniczenia ich kompetencji. Uczestniczący w zjeździe urzędnicy (przedstawiciele rządu) zaproponowali powołanie przy komisariatach wybieralnych rad gospodarczych, którym miały zostać powierzone sprawy dotyczące rolnictwa i dróg. Jednak czasem postanowiono rozszerzyć zakres ich kompetencji - miały one być zbliżone do rad powiatowych z czasów austro-węgierskich. Na zlecenie rządu L. Baczyński opracował tymczasową ordynację wyborczą, która zakładała powołanie rad złożonych z przedstawicieli różnych narodowości, wybranych w powszechnym i tajnym głosowaniu. Czynne prawo wyborcze otrzymały osoby powyżej 24. roku życia, bierne - które ukończyły 20 lat. Pod koniec grudnia 1918 r. w taki sposób została wyłoniona stanisławowska Powiatowa Rada Gospodarcza ${ }^{98}$. Jednak projekt

96 M. Stachiw, Zachidnia Ukrajina. Narys istoriji derżawnoho budiwnyctwa ta zbrojnoji i dyptomatycznoji oborony $w 1918-1923 \ldots$, t. IV, s. 86-88.

97 Ibidem, s. 87.

98 Wybory do hospodarśkoji rady powitowoji, „Nowe Zyttia”, 18 XII 1918. 
ten nie był szerzej realizowany, ponieważ komisarze powiatowi, którzy mieli odpowiadać za organizację wyborów do organów władzy lokalnej, nie byli zainteresowani w zmianą swoich uprawnień. Symptomatyczne jest to, że inicjowaniem i powoływaniem rad zajmowały się instytucje władzy wykonawczej różnych szczebli.

W procesie wdrażania do systemu ustrojowego zasad demokratycznych powiatowe rady narodowe stopniowo uzyskiwały status organów samorządowych, a ich rola rosła w podejmowaniu decyzji społecznych, gospodarczych, kulturalnych i edukacyjnych oraz innych kwestii dotyczących funkcjonowania gromad, miast i powiatów. Znaczenie miał fakt, że byli w nich reprezentowani cieszący się dużym autorytetem działacze polityczni i społeczni. Demokratyzował się też sposób rządzenia: w maju 1919 r. Rada Narodowa zajmowała się ustawą o powiatowych radach ludowych (pracowniczych), która zakładała, że będą one kontrolowały urzędników, a także dysponowały szerokimi uprawnieniami w zakresie rozwiązywania lokalnych problemów gospodarczych, oświatowych, społecznych, sanitarnych czy zaopatrzeniowych, ale nie zdążono jej przyjąć ${ }^{99}$.

Najsłabiej uporządkowane było najniższe ogniwo władzy przedstawicielskiej — rady gromadzkie w społecznościach wiejskich. Za czasów Austro-Węgier rady te były formowane według stanu społecznego: istniały trzy tzw. koła wyborcze, 2/3 miejsc w radach gromadzkich było zagwarantowanych dla przedstawicieli stanu szlacheckiego, w związku z czym liczebnie przeważający chłopi stanowili zaledwie $1 / 3$ ich radnych. Taka sytuacja doprowadziła do swoistego „wybuchu demokracji”, kiedy na początku listopada 1918 r., po przejęciu władzy przez Ukraińców, w gminach wiejskich na masowych zgromadzeniach powoływano nowe lokalne organy przedstawicielskie. Występowały one pod różnymi nazwami: społeczny komitet, urząd gromadzki, komitet ukraiński, gromadzki komisariat i mianowały się głównymi organami władzy w miejsce usuniętych starych wójtów i rad gromadzkich oraz utrzymywały porządek $\mathrm{w}$ terenie $\mathrm{e}^{100}$. Niemniej instytucja rady gromadzkiej się nie rozwinęła, jej rola i zadania nie zostały określone na poziomie legislacyjnym, zatem w trudnych realiach wojennych najszersze uprawnienia w zakresie rządzenia posiadali zastępujący wójtów gromadzcy komisarze.

Tworzone były również organy przedstawicielskie (rady) na podstawie kryterium przynależności zawodowej i społecznej. Niektóre z nich wzorowały się na radach deputowanych robotniczych, żołnierskich i chłopskich z Ukrainy Naddnieprzańskiej i były one w opozycji wobec władz ZURL-ZOURL, inne stanowiły formę solidarności korporacyjnej i jednocześnie angażowały się w proces państwowotwórczy oraz obronę młodej republiki — odnosi się to do rad wojskowych w Rudkach i w Przemyślu. W szczególności Rada Powiatowa w Rudkach, która powstała „pod wrażeniem rewolucji” i starała się nadać organizacji wojskowej „bardziej demokratyczny charakter”, ze względu na brak regularnych kontaktów z naczelnym dowództwem wzięła na siebie odpowiedzialność za

99 P. Haj-Nyżnyk, UNR $i$ ZUNR: stanowłennia orhaniw włady i nacionalne derżawotworennia (1917-1920 rr.), Kyjiw 2010, s. 211.

100 S. Makarczuk, Ukrajinśka Respublika hałyczan. Narysy pro ZUNR, Lwiw 1997, s. 55-56. 
działania żołnierzy, mające na celu utrzymanie porządku na terenie powiatu, oraz przeprowadzenie mobilizacji wśród ludności ${ }^{101}$.

Pod przywództwem komunistów i lewicowych socjalistów w 19 miastach i wsiach, które znajdowały się pod władzą ZURL, powstało 26 rad deputowanych, w tym 14 robotniczych, 5 - żołnierskich, 4 - chłopskie i 3 - zjednoczone. Miały one nie tyle stać się organami, reprezentującymi interesy tych grup, ile politycznym narzędziem radykalizacji nastrojów wśród ludności, w której żywe były idee rewolucyjne. Były to rady typu bolszewickiego, pełniły one niejako rolę komitetów strajkowych, miały przygotować i przeprowadzić zbrojne wystąpienia, stąd też nie znalazły większego poparcia.

Rady Deputowanych Żołnierskich, utworzone w niektórych jednostkach wojskowych Kołomyi, Stryja, Stanisławowa, znajdując się pod wpływem komunistycznej propagandy, starały się odsunąć od władzy „znienawidzonych” oficerów, komendantów miast, a nawet przedstawicieli władz cywilnych, prowadziły one również agitację antywojenną i antypaństwową. Opozycyjny charakter miały także robotnicze rady w Stebniku, Drohobyczu, powołane na walnych zgromadzeniach z udziałem odpowiednio 300 i 350 pracowników warzelni soli. Rady te postulowały podniesienie płac, rozwiązanie szeregu problemów społecznych i politycznych oraz miały swój udział w przygotowaniu jednego z największych buntów opozycji przeciwko oficjalnym władzom ZURL — powstania drohobyckiego w kwietniu 1919 r. Utworzona wówczas Zjednoczona Rada Robotniczo-Chłopska została ogłoszona organem władzy państwowej, zaś jej kolegialny organ kierowniczy — Komitet Rewolucyjny — zażądał przekazania władzy proletariatowi, jednak oddziały Armii Halickiej szybko rozbroiły tych powstańców i aresztowały ich przywódców ${ }^{102}$.

Ważne miejsce w systemie organów przedstawicielskich ZURL-ZOURL na różnych szczeblach zajmowały relacje z przedstawicielami mniejszości narodowych. Już w pierwszych publicznych odezwach Lwowska Ukraińska Rada Narodowa zadeklarowała równość wszystkich wspólnot narodowych Państwa Ukraińskiego, zagwarantowała im reprezentację $\mathrm{w}$ organach władzy i szeroką autonomię. Ugruntowana była świadomość tego, że wewnętrzna stabilność młodej republiki w dużej mierze zależy od normalizacji stosunków narodowościowych. W programowej „Proklamacji” z 19 października 1918 r. ${ }^{103}$ wezwano mniejszości, aby organizowały własne grupy publiczne i wysyłały swoich przedstawicieli do rad narodowych w liczbie proporcjonalnej do ich liczebności w społeczeństwie. Ponadto w specjalnej odezwie „Do ludności polskiej Lwowa" z 6 listopada zapewniano ją, że ,jej majątek, samorząd miejski oraz instytucje kulturalne i ekonomiczne" pozostają pod ochroną prawną państwa na równi z ukraińskimi. Podobne apele wystosowano również w innych miastach Galicji. Polacy jednak

101 O. Karpenko, Zachidno-Ukrainśka Narodna Respublika. 1918-1923. Istorija, Iwano-Frankiwśk 2001, s. 94-97.

102 Ibidem.

103 Proklamacja Ukrajinśkoji Nacionalnoji Rady, [w:] Konstytucijni akty Ukrajiny 1917-1920 rr. Newidomi konstytuciji Ukrajiny, Kyjiw 1992, s. 93. 
odmówili wstąpienia do głównego organu przedstawicielskiego ZURL — Ukraińskiej Rady Narodowej, co było równoznaczne z jej nieuznaniem (wiadomo, że jedynym jej polskim członkiem był E. Brejter, lecz z tego względu, że przebywał on we Wiedniu, było to członkostwo nominalne) ${ }^{104}$.

Lojalność względem mniejszości narodowych, jaką okazywały władze centralne, w jakiejś mierze wynikała $\mathrm{z}$ tego, że dążyły one jej uznania ze strony czynników międzynarodowych. W samej Radzie Narodowej nie było w tej sprawie jedności. Z jednej strony działacz z Naddnieprza W. Andrijewski podkreślał jej „wielką tolerancję” dla Polaków, Niemców i Żydów, ponieważ nie stosowano wobec nich represji i zawsze wyrażano się o nich „,Z wielkim szacunkiem" ${ }^{105}$. Z drugiej strony niektórzy posłowie na posiedzeniach Rady Narodowej występowali przeciwko „,zbyt dużej tolerancji w sprawach narodowościowych"106 i radzili, aby nie bawić się ze wspólnotą międzynarodową w „sentymentalne apele”, a zastosować wobec Polaków represje, aby w ten sposób doprowadzić do poprawy sytuacji Ukraińców internowanych w polskich obozach. Dlatego nie należy idealizować stosunku władzy przedstawicielskiej ZURL-ZOURL do społeczności polskiej, zwłaszcza że na szczeblu administracji lokalnej stosunki te pozostawały napięte.

Przedstawicieli mniejszości narodowych udało się włączyć do lokalnych wybieralnych organów władzy m.in. w drodze kompromisów, sprzecznych z deklaracjami władz centralnych i prawodawstwem ZURL, np. Polacy, niekiedy wraz z Żydami i Niemcami, wchodzili do rad powiatowych i miejskich organów samorządowych (m.in. Żółkiew, Ziemia Samborska, Ziemia Towmacka [Tłumacka]). Aby mogli oni brać udział w zarządzaniu miastem, ukraińska władza przedłużała uprawnienia starych rad miejskich, w których były reprezentowane różne narodowości, np. wybrany jeszcze za czasów Austro-Węgier magistrat Stanisławowa, na którego czele stał P. Czajkowski, funkcjonował do maja 1918 r. z zachowaniem autonomii zarządu miasta. De facto w starym składzie funkcjonowała rada miejska w Czortkowie, której znaczną część stanowili Polacy i Żydzi. Rada ta otrzymała prawo głosu doradczego oraz prawo do samodzielnego podejmowania uchwał. Podobna była sytuacja w Rudkach, magistrat w Złoczowie składał się głównie z Polaków, zaś w powiecie stryjskim z ich udziałem funkcjonowały dwie odrębne rady, tak zwana „ścisła” oraz „rozszerzona”, obydwie z prawem głosu doradczego ${ }^{107}$. Owe organy przedstawicielskie powstawały (były rekonstruowane) i funkcjonowały za zgodą ukraińskich komisarzy powiatowych oraz podlegały ich kontroli. Utrzymały pewne uprawnienia w zakresie rozwiązywania pilnych spraw społecznych i kulturalnych lokalnych społeczności. Obecność Polaków w radach sprzyjała stabilizacji życia narodowego i politycznego ZURL.

104 O. Pawłyszyn, Socialno-politycznyj portret ukrajinśkoho prowodu Hałyczyny ta Bukowyny w rewoluciji 1918-1919 rokiw..., s. 239.

105 W. Andrijewśkyj, Z mynułoho, t. II, Wid Het'mana do Dyrektoriji, cz. 2, Berlin 1923, s. 143.

106 Persze zasidannia Ukr. Nac. Rady, „Nowe Żyttia”, 4 II 1919.

107 O. Pawłyszyn, Polske nasełennia Schidnoji Hałyczyny pid władoju Zachidno-Ukrajinśkoji narodnoji Respubliky, ,Wisnyk Lwiwśkoho Uniwersytetu. Serija Istorija”, Lwiw 2000, nr 39-40, s. 211. 
W związku z powyższym ukraińskie władze zezwoliły na działalność struktur przedstawicielskich mniejszości narodowych, które miały swoją specyfikę. Głównym ośrodkiem koordynującym samoorganizację ludności polskiej na obszarze ZURL był utworzony w czasach Austro-Węgier Polski Komitet Narodowy w Stanisławowie. Zasiadała w nim 30-osobowa proporcjonalna reprezentacja przedstawicieli miejscowej inteligencji, partii „ludowców” i socjalistów. Komitet był związany z analogicznymi organizacjami w innych miastach: w Bohorodczanach, Buczaczu, Haliczu, Horodenku, Husiatynie, Monasterzyskach, Nadwornej i Czortkowie oraz wydawał im dyrektywy. Reprezentując interesy polskich mieszkańców miast i półlegalnych organizacji politycznych, instytucje te koordynowały działalność w zakresie rozwiązywania lokalnych problemów społecznych i oświatowych, oraz — podkreślając swoją odrębność od oficjalnych władz ukraińskich — nie wchodziły z nimi w otwarty konflikt ${ }^{108}$.

Za złożone można uznać relacje między przedstawicielami organów przedstawicielskich ZURL a Żydami, którzy wykazali się w wysokim poziomem samoorganizacji. Powstałe w wielu miejscowościach pod koniec 1918 r. Żydowskie Rady Narodowe reprezentowały interesy wszystkich warstw i organizacji politycznych. Rady te, w obawie przed zemstą, nie chciały ingerować w stosunki polsko-ukraińskie, więc najpierw zachowywały neutralność wobec władz ZURL i z tego względu odmówiły udziału w przeprowadzonych w dniach 22-26 listopada wyborach do Ukraińskiej Rady Narodowej. Następnie Żydowskie Rady Narodowe powołały wspólny organ przedstawicielski - Radę Tymczasową, która zamierzała zwołać Zgromadzenie Ustawodawcze Żydów Galicji Wschodniej. Kiedy Żydzi zrozumieli, że z powodu zmiany sytuacji na froncie ukraińsko-polskim urzeczywistnienie tego projektu nie będzie możliwe, 18 grudnia 1918 r. w Stanisławowie przeprowadzili zjazd Żydowskich Rad Narodowych z terytorium podporządkowanego ZURL. Na tym forum przedstawiciele 22 lokalnych rad powołali wspólną Żydowską Narodową Radę Galicji Wschodniej ${ }^{109}$.

W związku z żydowskimi pogromami na terenach kontrolowanych przez Polaków, Żydowskie Rady Narodowe zaczęły zmieniać swój stosunek do władz ZURL z neutralnego na nastawiony na porozumienie i współpracę. Żydzi dobrowolnie wstępowali w szeregi Armii Halickiej, w kwietniu 1919 r. sformowali w niej odrębny Kureń Żydowski, ich organizacje udzieliły ukraińskim władzom pożyczki pieniężnej, która została przeznaczona na pensje dla urzędników i wojskowych. Potwierdzeniem oficjalnego uznania postulatów żydowskiej mniejszości narodowej oraz gotowości do współpracy z nią były przeprowadzone wiosną $1919 \mathrm{r}$. pod protektoratem rządu ZURL wybory do Żydowskiej Rady Narodowej, która została uznana za oficjalny organ przedstawicielski mniejszości żydowskiej w kraju. Uwzględniono też propozycje Żydowskiej Rady Narodowej co do liczby ich przedstawicieli w przyszłym Sejmie ZURL (było to 27 miejsc, proporcjonalnie do liczebności tej mniejszości). Następnie

108 Ibidem, s. 213-215.

109 I. Pohrebynśka, M. Hon, Jewreji w Zachidnoukrajinśkij Narodnij Respublici. (Do probłemy ukrajinśko-jewrejśkych wzajemyn), Kyjiw 1997, s. 36-37, 41-42. 
w pięciu narodowych okręgach żydowskich odbyły się wybory do Sejmu, zwyciężyli w nich syjoniści ${ }^{110}$.

W grudniu 1918 r. w Stanisławowie delegaci społeczności niemieckiej utworzyli swój organ przedstawicielski - Niemiecką Radę Narodową w Republice Zachodnioukraińskiej. Jej przedstawiciele wyrażali chęć współuczestniczenia w opracowaniu przepisów o autonomii mniejszości narodowych i wezwali społeczność niemiecką do lojalności i wspierania władz państwa ukraińskiego ${ }^{111}$. Polityka ZURL-ZOURL była kształtowana zgodnie z zasadami demokracji, szacunku do wartości narodowych oraz świadczyła o chęci wykorzystania potencjału wszystkich wspólnot w budowie państwa wieloetnicznego.

Biorąc pod uwagę istniejące w naukach politycznych modele powoływania i funkcjonowania władzy ustawodawczej odnoszące się do współczesnych rozwiniętych demokracji, można stwierdzić, że władza ustawodawcza ZURL oraz jej relacje z władzą wykonawczą ewoluowały jako „mieszane” między prezydencko-parlamentarnym a gabinetowo-parlamentarnym z przewagą tego drugiego. Bezpośrednio na czele władzy wykonawczej stał przewodniczący (prezydent) rządu. Jego członkowie brali aktywny udział w pracach Rady Narodowej, ponosili osobistą odpowiedzialność za kierowany przez siebie resort. Kadencja parlamentu ZURL-ZOURL nie została zdefiniowana prawnie, gdyż Rada miała status „organu tymczasowego” i miała funkcjonować do czasu zwołania Zgromadzenia Ustawodawczego, powołanego w drodze powszechnych demokratycznych wyborów. Mimo formalnej nadrzędności organu ustawodawczego gabinet ministrów miał znaczny, niekiedy wyłączny wpływ na jego pracę jako instytucja inicjująca i realizująca kurs polityczny. Większość projektów ustaw zgłaszali bowiem członkowie rządu, a następnie w parlamencie popierali je ich partyjni sojusznicy. W takich warunkach sprawczość i efektywność Rady Narodowej polegała na wypracowaniu polityki państwa i bazy legislacyjnej w drodze politycznego, społecznego i narodowego konsensu. Oprócz określenia sposobu reformowania poszczególnych dziedzin życia społecznego, rada bezpośrednio angażowała się w rozwiązywanie różnych trudnych problemów bieżących. W warunkach napiętej sytuacji wojskowej i politycznej model ten okazał się optymalny i wystarczająco skuteczny, ponieważ pozwalał szybko reagować na nowe wyzwania i szybko podejmować odpowiednie decyzje.

III. WNIOSKI

1. Ważnym czynnikiem rozwoju ukraińskiej państwowości w okresie ukraińskiej rewolucji był fakt, że ludność nieukraińską udało się włączyć w struktury władzy przedstawicielskiej i wykonawczej. Jako pierwsza uczyniła to Ukraińska Centralna Rada, która nie tylko zadeklarowała, że jednym z jej priorytetów jest zagwarantowanie

110 Ibidem, s. 44-49.

111 Vide I. Monołatii, Polityka Zachidnoukrajinśkoji Narodnoji Respubliky szczodo nimeckoji nacionalnoji menszyny (1918-1919 r.), „Wisnyk Kyjiwśkoho Nacionalnoho Linhwistycznoho Uniwersytetu”, serija „Istorija, Ekonomika, Fiłosofija”, Kyjiw 2001, nr 5, s. 136-147. 
praw mniejszościom narodowym, ale także $\mathrm{w}$ różny sposób dążyła do podjęcia $\mathrm{z}$ nimi współpracy. Porozumienie co do uznania przez przedstawicieli ludności nieukraińskiej autonomii narodowo-terytorialnej Ukrainy oraz ich wejścia do Centralnej Rady zostało osiągnięte 26-28 czerwca 1917 r. Co prawda, nierozwiązana pozostała kwestia liczebnej reprezentacji: ukraińscy przedstawiciele proponowali mniejszościom narodowym $25 \%$, zaś same mniejszości żąałały dla siebie połowy miejsc w Centralnej Radzie.

Za najbardziej odpowiedni sposób uzupełnienia składu narodowościowego Centralnej Rady uznano reprezentację proporcjonalną. Zgodnie z nią liczba mandatów poselskich, jaką miały otrzymać mniejszości narodowe, procentowo odpowiadałaby liczebności poszczególnych mniejszości na Ukrainie. Zasady podziału mandatów były uzależnione od politycznych preferencji Centralnej Rady: reprezentantami mogli zostać przede wszystkim przedstawiciele ,zorganizowanej rewolucyjnej demokracji”, czyli rady deputowanych robotniczych i żołnierskich oraz partie socjalistyczne. Narodowości, które nie znalazły swojej reprezentacji w spektrum partii socjalistycznych, mogły być reprezentowane przez organizacje o charakterze ogólnonarodowym. Wadą takiego sposobu przedstawicielstwa w Centralnej Radzie było to, że podczas jej uzupełnienia pierwszeństwa udzielano przede wszystkim rewolucyjnym partiom socjalistycznym, które nie odzwierciedlały pełnego spektrum interesów społeczno-politycznych mniejszości narodowych, a w zasadzie i całego społeczeństwa ukraińskiego. Potwierdzeniem prawdziwości intencji Centralnej Rady, że zamierzała ona zapewnić mniejszościom narodowym możliwość samodzielnego zorganizowania swego życia na terytorium Ukrainy, było podniesienie statusu wicesekretariatów do spraw spraw rosyjskich, żydowskich i polskich. Wszelkie rozporządzenia Sekretariatu Generalnego oraz jego organów, dotyczące spraw wewnętrznych i praw mniejszości narodowych, wchodziły w życie dopiero po ich zatwierdzeniu przez zastępców sekretarza generalnego do spraw narodowości. W swojej pracy wicesekretariaty miały posługiwać się językiem danej mniejszości narodowej. Taka postawa przywódców ukraińskiej rewolucji niezbicie świadczyła o ich dążeniu do osiągnięcia w kraju stanu porozumienia między grupami narodowymi i etnicznymi.

2. Proces tworzenia organów przedstawicielskich ZURL-ZOURL był związany ze strukturami monarchii habsburskiej, dlatego ukraińscy politycy starali się nadać im charakter narodowy i zmodernizować zgodnie z demokratycznym modelem rządzenia i ustrojem republikańskim Państwa Ukraińskiego, które zostało proklamowane w październiku 1918 r. na ziemiach zachodnioukraińskich, a następnie Zachodnioukraińskiej Republiki Ludowej (Zachodniego Obwodu URL). Pomimo tych okoliczności i faktu nieprzeprowadzenia wyborów powszechnych Rada Narodowa funkcjonowała jako pełnoprawny organ prawowodawczy, który swoim poziomem dorównywał parlamentom innych krajów europejskich. Kierownicze struktury Rady miały szczególne kompetencje: o ile Prezydium pełniło funkcje czysto techniczne, organizacyjne, to Wydział stał się organem kolegialnym o uprawnieniach w zakresie „odpowiadającym uprawnieniom" urzędu prezydenckiego. W kwestii podejmowania ważnych decyzji funkcjonował mechanizm osiągnięcia konsensu między frakcjami różnych partii. Zarazem 
instytucja samorządu terytorialnego nie została pod względem prawnym rozwinięta, chociaż dominowała tendencja do rozszerzenia jego praw i kompetencji.

Charakter uchwalanego prawodawstwa Zachodnioukraińskiej Republiki Ludowej determinowały trudne warunki, w jakich działała Rada Narodowa, oraz stojące przed nią zadania w sferze społecznej i politycznej. Większość dokumentów przyjętych w warunkach demokracji parlamentarnej było wyrazem dążenia do rozwoju państwowości narodowej i zapewnienia praw i swobód jednostki. W tym Rada Narodowa aktywnie wykorzystywała zarówno zdobycze konserwatywnej monarchii austro-węgierskiej, jak i rewolucyjno-socjalistycznej Ukraińskiej Republiki Ludowej, orientując się na zasady rozwoju państwa wdrażane przez Centralną Radę i Dyrektoriat: niezależność, suwerenność, trójpodział władz, równość obywateli wobec prawa, prawo mniejszości narodowych do swobodnego rozwoju.

Zwięzłość treści i niepełność uchwalanych aktów prawnych nie są dowodem na głębię i dojrzałość procesu politycznego, a wyrazem wojskowo-politycznych uwarunkowań oraz konieczności ich uchwalania. Ze względu na swoją istotę i zawartość większość aktów prawnych, regulujących funkcjonowanie ZURL, stanowiły modyfikację aktów Austro-Węgier, które najpierw (listopad 1918 r.) figurowały jako „tymczasowe”, zaś następnie (styczeń, kwiecień 1919 r.) uzyskały status ustaw długoterminowych. W prawodawstwie ZURL dominował kierunek liberalny, socjalistyczny mu wyraźnie ustępował, był znacznie słabszy niż w URL. Zarazem w każdym z nich ściśle się ze sobą przeplatały tendencje liberalno-narodowe oraz socjalno-narodowe. Wybór republikańskej formy ustrojowej, opartej na fundamencie zmodernizowanego prawa monarchicznego, był w dużej mierze wyborem uzasadnionym, ponieważ stworzenie nowej bazy prawnej wymagało czasu i dużego wysiłku.

BIBLIOGRAFIA

ŹRÓDŁA

Centralnyj deržavnyj archiv hromadśkych objednań Ukrajiny (m. Kyjiv), fond 5 (Komisija z istoriji Hromadanśkoji vijny pry CK KP(b)U. 1917-1938 rr.), opys 1, sprava 265 (Peredruky materialiv pro borobu $\mathrm{z}$ bandamy Maxno, Hryhorjeva ta in. Berezeń-lypeń 1919 r.).

Centralnyj deržavnyj archiv vyščych orhaniv vlady ta upravlinńa Ukrajiny (m. Kyjiv), fond 1115 (Ukrajinśka Centralna Rada 1917-1918 rr.), opys 1, sprava 2 (Komunikat Polśkoho vykonavčoho komitetu na Rusi do Centralnoji Rady z pytań samostijnoji Ukrajiny. 30 červńa-30 veresńa 1917 r.).

Centralnyj deržavnyj archiv vyščyx orhaniv vlady ta upravlinńa Ukrajiny (m. Kyjiv), fond 2201 (Ministerstvo osvity Ukrajinśkoji Deržavy. 1918 r.), opys 1, sprava 17 (Lystuvanńa z sekretarem nacional'nych sprav pro orhanizaciju osvity učniv, pojasńuval'na zapyska do štativ Ministerstva pośkych sprav. 1918 r.).

Centralnyj deržavnyj istoryčnyj archiv Ukrajiny u L'vovi, fond 581 (Kolekcija dokumentiv pro dijalnist' ứadiv i armij Ukrajinśkoji Narodnoji Respubliky ta Zachidno-Ukrajinśkoji Narodnoji Respubliky), opys 1, sprava 96 (Zakonoproekty, zakony, rozpoŕadženńa ta cyrkuary uŕadu ZUNR pro deržavnu administraciju, vybory v sejm ZUNR, zemelnu ta hrošovu reformy, oplatu včyteliv ta inše. 16 lystopada 1918 r.-červeń 1919 r.). 
Ukrajinśka Centralna Rada. Dokumenty i materialy: u 2 t., t. 1: 4 berezńa-9 hrudńa 1917 r., red. V. Smolij, Naukova dumka, Kyjiv 1996.

Ukrajinśka Centralna Rada. Dokumenty i materialy: u 2 t., t. 2: 10 hrudńa 1917 r.-29 kvitńa 1918 r., red. V. Smolij, Naukova dumka, Kyjiv 1997.

Ukrajinśkyj nacionalno-vyzvol'nyj ruch. Berezeń-lystopad 1917 r. Dokumenty i materialy (upoŕad. V. Verst'uk), Vydavnyctvo im. Oleny Telihy, Kyjiv 2003.

Zachidno-Ukrajinśka Narodna Respublika. 1918-1923: Dokumenty i materialy u 5-ty tomax. t. 2: Deržavotvorči j administratyvno-orhanizacijni procesy (ukl. O. Karpenko, K. Mycan), Lileja-NV, Ivano-Frankiwśk 2001.

\section{PIŚMIENNICTWO}

Andrijevśkyj V., Z Mynuloho, Vid Het’mana do Dyrektoriji, t. II, cz. 2, Vydavnyctvo „Ukrajinśke Slovo", Berlin 1923.

Čerykover Y., Antysemytyzm y pohromü na Ukrayne 1917-1918 hh. (K istorii ukraynskoevrejskych otnošenyj), Ostjudisches Historisches Archiv, Berlin 1923.

Čubatyj M., Deržavnyj lad na Zachidnij Oblasty Ukrajinśkoji Narodńoji Respublyky, L'viv, 1921.

Goldelman S.I., Žydivśka nacional’na avtonomija v Ukrajini 1917-1920, Dniprova Chvyla, Miunchen-Paryž-Jerusaīym 1967.

Haj-Nyžnyk P., UNR i ZUNR: stanovlenńa orhaniv vlady $i$ nacionalne deržavotvorenńa (1917-1920 rr.), „ŠčeK”, Kyjiv 2010.

Hruševśkyj M., Vil’na Ukrajina, Ukrajinśka Drukarńa i Vydavnyča Spilka, Ńju-Jork 1918.

Hruševśkyj M., Chto taki ukrajinci i čoho vony chočut', Tovarystvovo Znanńa Ukrajiny, Kyjiv 1991.

Jabłoński H., Polska autonomia narodowa na Ukrainie 1917-1918, Towarzystwo Miłośników Historii, Warszawa 1948.

Janevśkyj D., Polityčni systemy Ukrajiny 1917-1920 rokiv: sproby tvorenńa i pryčyny porazky, Duch i Litera, Kyjiv 2003.

Karpenko O., Zachidno-Ukrajinśka Narodna Respublika. 1918-1923: Istorija, Siversija, Ivano-Frankiwśk, 2001.

Khrystuk P., Zamitky i materijaly do istoriji ukrajinśkoji revoluciji 1917-1920 rr., t. I, Vydavnyctvo Čartoryjśkyx, Ńju-Jork 1969.

Knyha o russkom evrejstve. 1917-1967, red. Ja.H. Frumkyna, H.Ja. Aronsona, A.A. Hol'denvejzera, Sojuz Russkych Evreev, Ńju-Jork 1968.

Kudlaj O., Stvorenńa ta dijalnist' narodnoho ministerstva mižnarodnych sprav Ukrajinśkoji Narodnoji Respubliky (červeń 1917-kviteń 1918 rr..), NAN Ukrajiny; Instytut Istoriji Ukrajiny, Kyjiv 2008.

Levyćkyj K., Velykyj Zryv, Červona Kalyna, L’viv 1931.

Makarčuk S., Ukrajinśka Respublika halyčan. Narysy pro ZUNR, Svit, L'viv 1997.

Monołatii I., Polityka Zachidnoukrajinśkoji Narodnoji Respubliky szczodo nimeckoji nacionalnoji menszyny (1918-1919 r.), „Wisnyk Kyjiwśkoho Nacionalnoho Linhwistycznoho Uniwersytetu”, serija „Istorija, Ekonomika, Fiłosofija”, Kyjiw 2001, nr 5

Monołatii I., Walak M., Ukraińska idea państwowa - próby urzeczywistnienia, [w:] Wprowadzenie do studiów wschodnioeuropejskich, t. 2, Ukraina i Białoruś: przeszłość i współczesność ziem między Rzeczypospolita a Rosja, red. W. Paruch, Uniwersytet Marii Curie-Skłodowskiej, Lublin 2013.

Myronenko O., Heneral’ne sekretarstvo (ministerstvo) z rosijśkych sprav UNR, [w:] Mala encyklopedija etnodepžavoznavstva, Kyjiv 1996. 
Pančuk M., „Bili plamy” herojičnoho litopysu. Iz istoriji Komunistyčnoji partiji na Zachidnij Ukrajini, Politvydav, Kyjiv 1989.

Pančuk M., Nacionalni menšyny Ukrajiny u XX stolitti: polityko-pravovyj aspekt, NAN Ukrajiny, Instytut Polityčnych i Etnonacional'nych Doslidžeń, Kyjiv 2000.

Pavlyšyn O., Socialno-polityčnyj portret ukrajinśkoho provodu Halyčyny ta Bukovyny v revoluciji 1918-1919 rokiv, „Ukrajina Moderna” 2000, nr 4-5.

Pohrebynśka I., Hon M., Jevreji v Zaxidnoukrajinśkij Narodnij Respublici. (Do problemy ukrajinśko-jevrejśkych vzajemyn), Nacionalna Akademija Nauk Ukrajiny; Instytut Politolohiji i Mižnacionalnych Vidnosyn, Kyjiv 1997.

Skalśkyj V., Polityčne žytt’a pol'śkoji hromady pid čas Ukrajinśkoji revoluciji (berezeń 1917- kviteń 1918 rr.), „Ukrajinśkyj Istoryčnyj Zbirnyk” 2008, nr 11.

Stakhiv M., Zachidńa Ukrajina. Narys istoriji deržavnoho budivnyctva ta zbrojnoji i dyplomatyčnoji oborony v 1918-1923. t. 4, cz. 6, Ukrajinśkyj Robitnyčyj Sojuz, Skrenton 1962. 